\title{
National Environmental Policy Act Hazards Assessment for the TREAT Alternative
}

\author{
Boyd D. Christensen
} Annette L. Schafer

November 2013

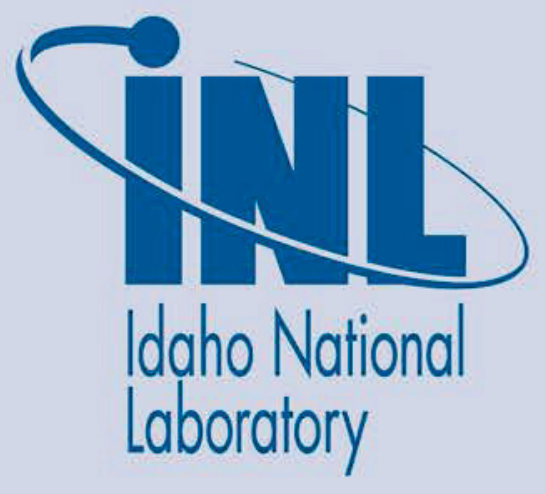

The INL is a U.S. Department of Energy National Laboratory operated by Battelle Energy Alliance 
INL/EXT-13-29496

\title{
National Environmental Policy Act Hazards Assessment for the TREAT Alternative
}

\author{
Boyd D. Christensen \\ Annette L. Schafer
}

November 2013

\begin{abstract}
Idaho National Laboratory
Idaho Falls, Idaho 83415
\end{abstract}

http://www.inl.gov

\author{
Prepared for the \\ U.S. Department of Energy \\ Office of Nuclear Energy \\ Under DOE Idaho Operations Office \\ Contract DE-AC07-05ID14517
}




\section{DISCLAIMER}

This information was prepared as an account of work sponsored by an agency of the U.S. Government. Neither the U.S. Government nor any agency thereof, nor any of their employees, makes any warranty, expressed or implied, or assumes any legal liability or responsibility for the accuracy, completeness, or usefulness, of any information, apparatus, product, or process disclosed, or represents that its use would not infringe privately owned rights. References herein to any specific commercial product, process, or service by trade name, trade mark, manufacturer, or otherwise, does not necessarily constitute or imply its endorsement, recommendation, or favoring by the U.S. Government or any agency thereof. The views and opinions of authors expressed herein do not necessarily state or reflect those of the U.S. Government or any agency thereof. 



\begin{abstract}
This document provides an assessment of hazards as required by the National Environmental Policy Act for the alternative of restarting the reactor at the Transient Reactor Test (TREAT) facility by the Resumption of Transient Testing Program. Potential hazards have been identified and screening level calculations have been conducted to provide estimates of unmitigated dose consequences that could be incurred through this alternative. Consequences considered include those related to use of the TREAT Reactor, experiment assembly handling, and combined events involving both the reactor and experiments. In addition, potential safety structures, systems, and components for processes associated with operating TREAT and onsite handling of nuclear fuels and experiments are listed. If this alternative is selected, a safety basis will be prepared in accordance with 10 CFR 830, "Nuclear Safety Management," Subpart B, "Safety Basis Requirements."
\end{abstract}




\section{CONTENTS}

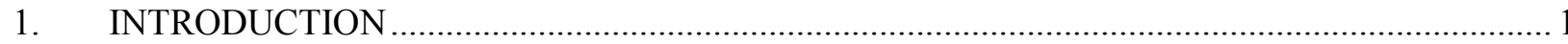

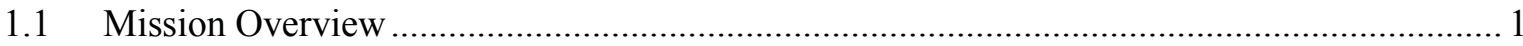

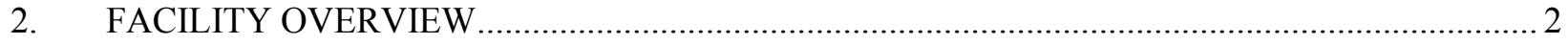

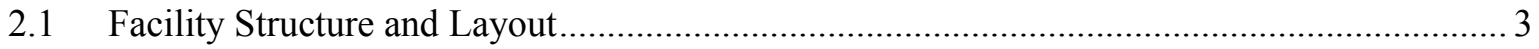

3. HAZARDS IDENTIFICATION AND INTERPRETATION .................................................. 4

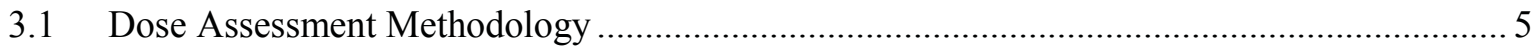

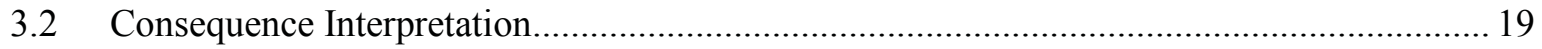

4. UNMITIGATED DESIGN BASIS ACCIDENT ANALYSES …........................................... 19

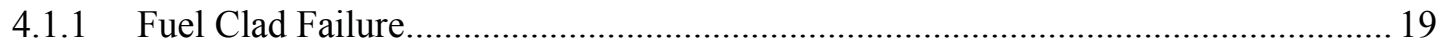

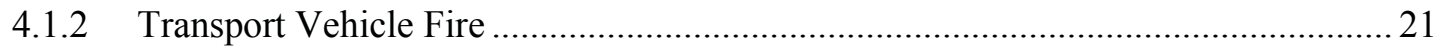

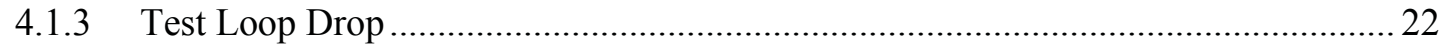

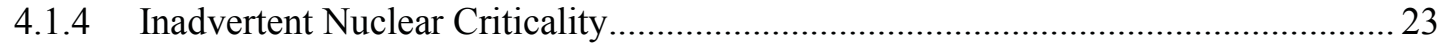

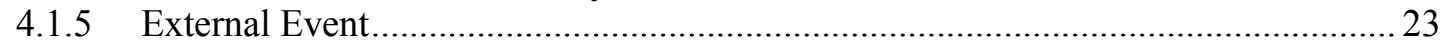

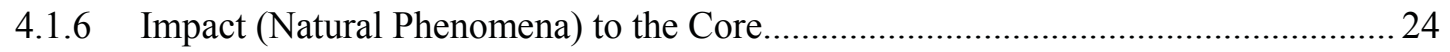

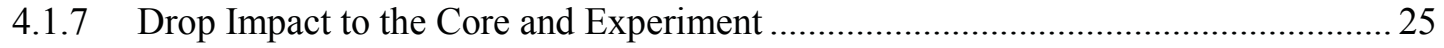

4.1.8 Sodium Fire Impacting the Core and Experiment.................................................28

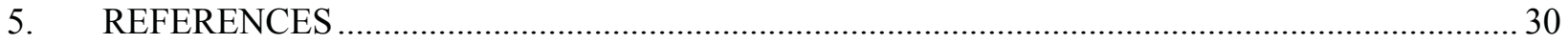

\section{FIGURES}

1. Cutaway view of the reactor building (MFC-720) at the Transient Reactor Test Facility ........... 3

2. Schematic showing the TREAT Reactor building (MFC-720) main floor layout...................... 4

\section{TABLES}

1. Preliminary hazards identified for restart of the TREAT Reactor and use of the TREAT facilities

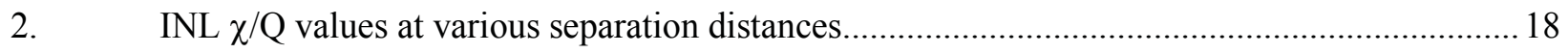

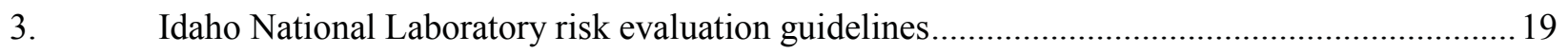

4. Release factors for a fuel clad failure caused by excessive reactivity, resulting in airborne releases 


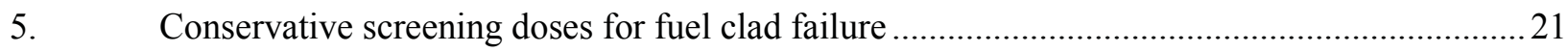

6. Release factors for airborne releases from a transport vehicle fire.......................................2 21

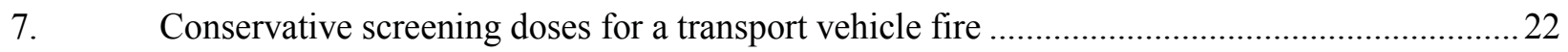

8. Release factors for airborne releases from a test loop drop ............................................23

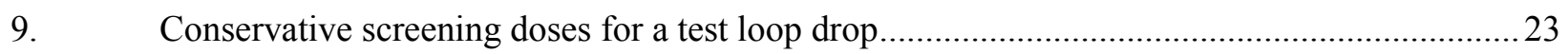

10. Release factors for airborne releases from a seismic event ..............................................24

11. Conservative screening doses for an impact to the TREAT Reactor core................................25

12. Release factors for test loop plus reactor core airborne release................................................2 27

13. Conservative screening doses for impact of the reactor core by the experiment......................22

14. Release factors for a sodium fire that results in airborne releases ......................................29 


\section{ACRONYMS}

$\begin{array}{ll}\text { ARF } & \text { airborne release fraction } \\ \text { CED } & \text { committed effective dose } \\ \text { DBA } & \text { design-basis accident } \\ \text { DOE } & \text { Department of Energy } \\ \text { DR } & \text { damage ratio } \\ \text { F/CS } & \text { filtration/cooling system } \\ \text { EG } & \text { evaluation guideline } \\ \text { HEPA } & \text { high-efficiency particulate air } \\ \text { INL } & \text { Idaho National Laboratory } \\ \text { LPF } & \text { leak path factor } \\ \text { MAR } & \text { material at risk } \\ \text { MFC } & \text { Materials and Fuels Complex } \\ \text { NEPA } & \text { National Environmental Policy Act } \\ \text { RF } & \text { respirable fraction } \\ \text { SSC } & \text { structure, system, and component } \\ \text { ST } & \text { source term } \\ \text { TREAT } & \text { Transient Reactor Test }\end{array}$




\section{National Environmental Policy Act Hazards Assessment for the TREAT Alternative \\ 1. INTRODUCTION}

This document provides an assessment of hazards as required by the National Environmental Policy Act (NEPA) (42 USC $\S 4321$ et seq.) for the alternative of restarting the reactor at the Transient Reactor Test (TREAT) facility by the Resumption of Transient Testing Program. Potential hazards are identified and screening level calculations are provided for unmitigated dose consequences that could be incurred through this alternative. Consequences considered include those related to use of the TREAT Reactor, experiment assembly handling, and combined events involving both the reactor and experiments. If this alternative is selected, a documented safety analysis for the facility and experiments will be prepared as required by 10 CFR 830, "Nuclear Safety Management," Subpart B, "Safety Basis Requirements."

In accordance with the U.S. Department of Energy (DOE) "Recommendations for Analyzing Accidents under the National Environmental Policy Act” (DOE 2002) and 10 CFR 830, Subpart B, this document provides a broad-based overview of the following:

- The types of operations proposed for the Resumption of Transient Testing Program, which include operating the TREAT Reactor, reactor refueling, experiment handling, insertion, irradiation of the experiments using the reactor, and combinations of these operations.

- Hazards associated with the identified operations, with identification of hazards limited to those that could occur at TREAT. Activities associated with use of other facilities at the Idaho National Laboratory (INL), including, but not limited to, the Advanced Test Reactor, Hot Fuel Examination Facility at the Materials and Fuels Complex (MFC), and the Idaho Nuclear Technology and Engineering Center (Building 666), will be subject to the unreviewed safety question process in each of those facilities to determine if that activity is bounded by its respective safety basis. Hazards associated with operation of the TREAT Reactor during transient testing would not involve other facilities, and the potential to impact the current storage mission of TREAT is not credible on account of the robust design of the reactor structure and subsurface storage areas (ECAR-2184 2013).

- A preliminary identification of safety functions that would be assessed. If resumption of transient testing using the TREAT facility is selected after completion of the NEPA process, all required safety analyses will be conducted in accordance with the requirements of 10 CFR 830, Subpart B. These safety analyses are driven by the need to carefully establish the engineering evaluation of and nuclear safety design criteria for safety-class and safety-significant structures, systems, and components (SSCs) using the required evaluation guidelines.

\subsection{Mission Overview}

The primary mission of the DOE Office of Nuclear Energy is to advance nuclear power as a resource capable of making major contributions in meeting the nation's energy supply, environmental, and energy security needs. This is accomplished by resolving technical, cost, safety, security, and proliferation-resistance barriers through research, development, and demonstration, as appropriate. The DOE Office of Nuclear Energy's research and development activities will help address these challenges, thereby enabling development of new reactor technologies that will support the current fleet of reactors and facilitate construction of new ones.

The DOE Office of Nuclear Energy organizes its research and development activities along the following four main objectives that address challenges to expanding the use of nuclear power:

1. Develop technologies and other solutions that can improve reliability, sustain safety, and extend the life of current reactors 
2. Develop improvements in the affordability of new reactors to enable nuclear energy to help meet the Administration's energy security and climate change goals

3. Develop sustainable nuclear fuel cycles

4. Understand and minimize the risks of nuclear proliferation and terrorism.

Development and licensing of improved and new forms of fuel for nuclear power production requires testing of nuclear fuels under postulated reactor accident conditions. Significant transient testing of nuclear fuels has not been conducted in the United States in over a decade, and there are very few test facilities in the world where transient testing of prototype-scale fuel pins can take place.

Transient test reactors must have the ability to induce specific phenomenological changes to nuclear fuel systems. The phenomenological changes of interest are induced by short bursts of intense, high-power radiation. Nuclear fuel systems in this context are comprised of nuclear fuel, coolant, pumps to circulate the coolant past the nuclear fuel, and onboard instrumentation. The nuclear fuel system being tested is contained in an experiment assembly. The test reactor must be able to accommodate the experiment assembly in the reactor core. The requirements of transient test reactors also include in-situ, real-time imaging technology using a radiation detection system such as a hodoscope. This technology provides the time evolution of fuel damage, which is key to developing a thorough understanding of the underlying science of fuel behavior. In-situ imaging is augmented by post-irradiation examination to confirm the condition of the fuel during and after testing.

The alternative test reactors being considered for use and being assessed by the program's environmental assessment include the reactor at the TREAT facility at INL's MFC and the Annular Core Research Reactor at Sandia National Laboratory in New Mexico.

\section{FACILITY OVERVIEW}

The TREAT Reactor is located within a fenced area northwest of the main MFC area at INL. TREAT is approximately 11 miles from INL's east boundary and 4 miles north of U.S. Highway 20. Structures and areas adjacent to TREAT, but not included within the TREAT boundary, are the TREAT warehouse (MFC-723), an access guardhouse (MFC-722), a material/equipment lay down area in the north portion of the site, and interim parking in the east portion of the site for INL space battery program trailers. The TREAT control room (MFC-724) is located about 0.5 miles southeast of the reactor building.

The TREAT facility (MFC-720; Figure 1) was constructed in 1958 to evaluate reactor fuels and structural materials under conditions simulating various types of nuclear excursions and transient over-power and under-cooling situations. In addition to conducting transient experiments, the TREAT Reactor was built to allow neutron radiography of experimental capsules and fuel elements that had been irradiated in TREAT or in other reactors. The original facility included the TREAT Reactor, below grade fuel storage, a reactor filtration/cooling system (F/CS), and an overhead crane. The reactor first achieved criticality on February 23, 1959. Subsequent modifications to TREAT resulted in expansion of the building superstructure; construction of additional below grade fuel storage and experiment test loop storage capacity; installation of a 60-ton overhead crane; addition of a collection system for suspect liquid waste; and upgrades to facility safety and support systems (e.g., electrical, heating, ventilation, and air conditioning) to support continued and expanded reactor operations.

The TREAT Reactor has been in a cold standby configuration since 1994. The reactor remains fueled with control rods fully inserted and rod drive systems electrically disconnected to prevent operations. Subsequent to reactor inactivation, the primary missions performed in the TREAT Reactor building (MFC-720) have included storage of TREAT Reactor fuel and other nuclear materials and facility and system maintenance, with inspection of the reactor and reactor systems as a secondary mission. Other activities performed in the TREAT Reactor building during cold standby mode have included demonstration of a plasma hearth treatment technology and operation of an analytical chemistry 
laboratory, both are no longer in operation. The Plasma Hearth Project enclosure and miscellaneous equipment have been abandoned in-place (south high bay). Current activities and operations performed in the TREAT Reactor building include the following:

- Inspection and surveillance of nuclear material stored in the facility

- Radioactive and nuclear material receipt, storage, and handling (e.g., radioactive sources)

- Non-reactor training and experiments involving radioactive material and radiation-generating devices

- Maintenance of the facility structure and equipment therein.

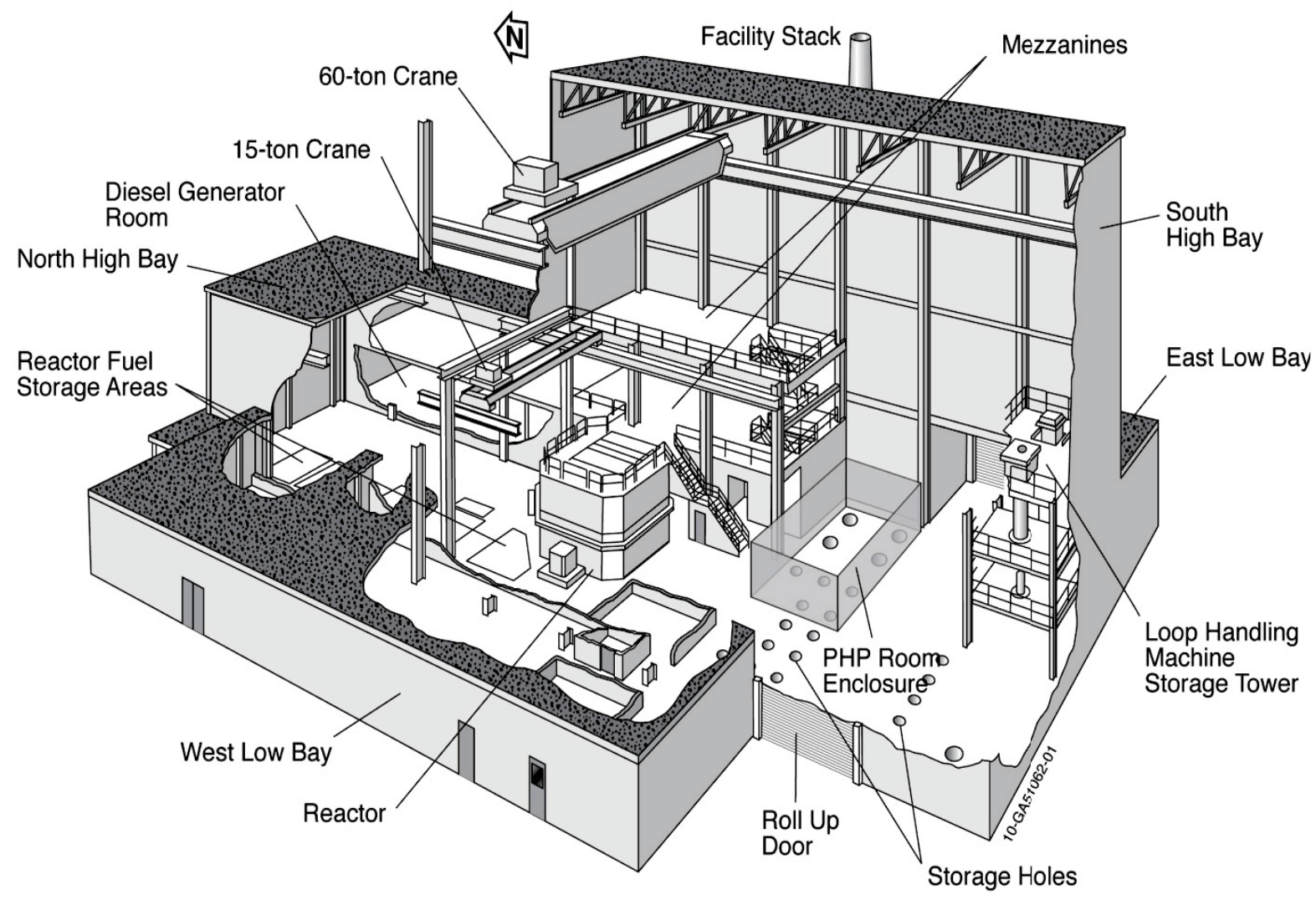

Figure 1. Cutaway view of the reactor building (MFC-720) at the Transient Reactor Test Facility.

\subsection{Facility Structure and Layout}

The TREAT facility includes the TREAT Reactor, below grade fuel and experiment test loop storage, a reactor F/CS, and two overhead cranes. In 1988, the reactor underwent its latest upgrade, which included installation of new instrumentation and control systems and upgrades to and refurbishment of the rod drive systems (Figure 2). The TREAT control room (MFC-724) is located about 0.5 miles southeast of the reactor building. The control room is connected to the TREAT Reactor building via buried cables for transmission of operator commands and receipt of reactor status signals. The TREAT Reactor building receives electric power from the INL grid and water supply from the firewater system at MFC. 


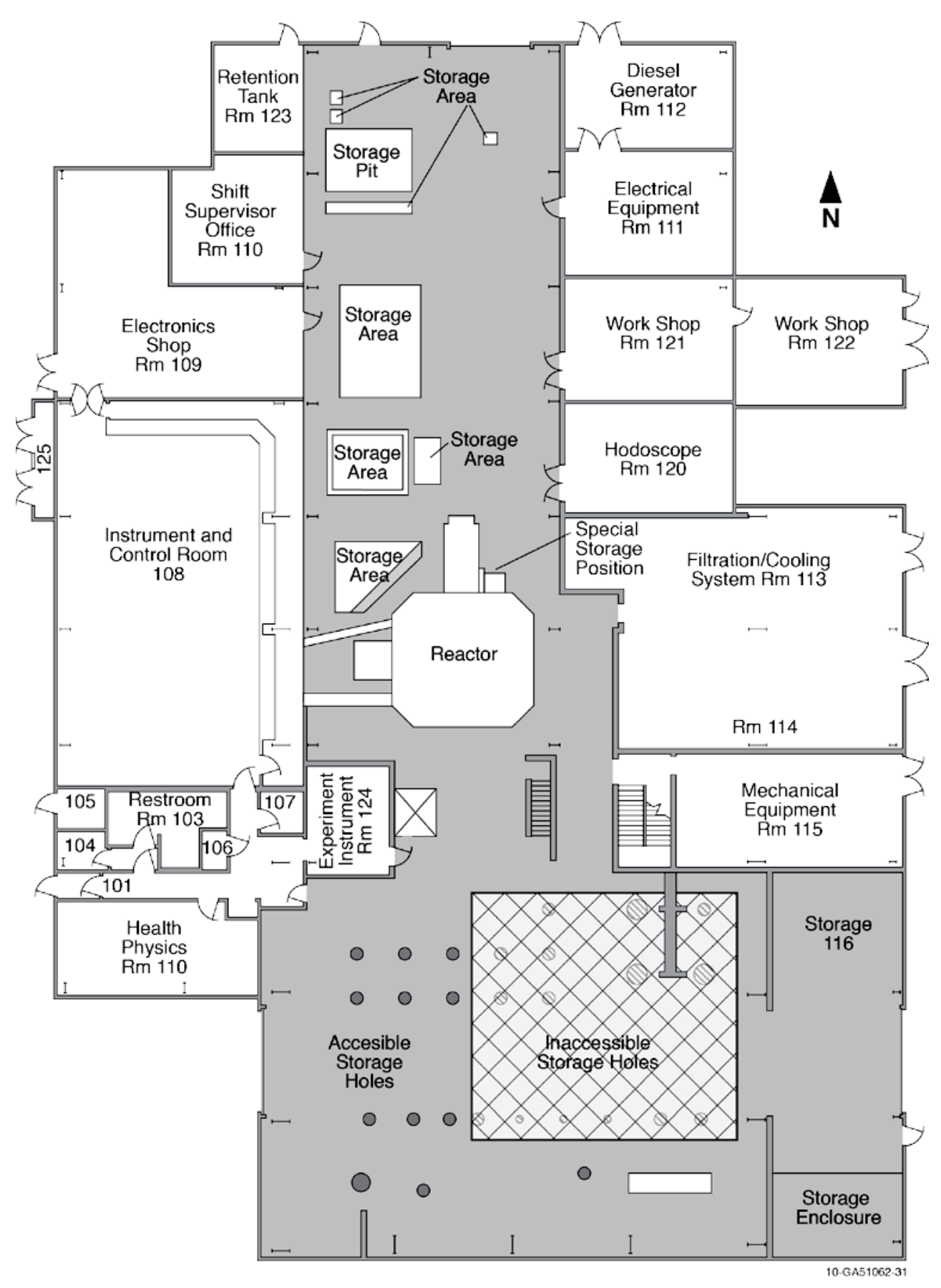

Figure 2. Schematic showing the TREAT Reactor building (MFC-720) main floor layout.

\section{HAZARDS IDENTIFICATION AND INTERPRETATION}

The hazards that have the potential to result in an uncontrolled release of radioactive or hazardous materials and affect the offsite public, collocated workers, facility workers, or the environment are required to be evaluated (DOE 2002). A list of potential hazards has been developed to allow a screening-level evaluation of potential radiologic dose consequences. The list is based on the 34-year operating history of the TREAT Reactor and lessons learned. The preliminary identification of hazards allows the definition of design basis accidents (DBAs) and the preliminary identification of safety SSCs or administrative controls that could be used to prevent or mitigate the consequences of the accidents. 
Credit could be taken for the safety SSCs and administrative controls in the preliminary assessment of accident consequences. If restart of the TREAT Reactor is selected through the NEPA process, detailed dose consequence analyses will be completed in conjunction with development of the documented safety analysis, which will determine the final designation of safety SSCs and administrative controls.

Table 1 lists the preliminarily identified hazards and causes and possible preventative and mitigative measures. The table is not intended to represent or meet the need of the safety basis documentation that will be required if restart of the TREAT Reactor is selected as the preferred alternative under NEPA. If this alternative is selected and at the time the safety basis documentation is developed, some potential accidents may be eliminated from further consideration or others may be added.

The hazardous events, initiators, and initiator likelihoods shown in the first three columns of Table 1 primarily were garnered from historical operating experience and subject matter expert elicitation. Because Table 1 shows a preliminary identification of hazards, detailed descriptions of each hazard event are not presented. Based on the elicitation process, an expert judgment consequence category was assigned to each event for facility workers, collocated workers, and members of the public. The consequence categories shown in Table 1 are discussed in Section 3.2.

DOE guidance for NEPA accident analyses (DOE 2002) allows inclusion of mitigation in determining the radiological risk; however, the hazard consequences provided in the following subsections are the unmitigated values that follow INL GDE-10820, "INL Guide to Safety Analysis Methodology," methodology to illustrate the bounding radiological risk. The potential mitigative features (such as an engineered feature or an administrative action) that could be required are noted in the final two columns of Table 1 .

Based on the contents of Table 1, several of the postulated events were determined to be representative, bounding, or unique accidents. These accident scenarios, defined as DBAs, include the following:

- $\quad$ Fuel clad failure (bounds all reactivity insertion accidents)

- $\quad$ Transport vehicle fire (bounds all fire and explosion events)

- $\quad$ Test loop drop (bounds all radioactive material release or direct radiation exposure events)

- Inadvertent nuclear criticality

- $\quad$ External events (consequences bounded by other events)

- $\quad$ Severe seismic event (bounds all natural phenomena hazard events)

- $\quad$ Events involving mechanical failure of the experiment loop while in the TREAT Reactor.

Experience in other reactor facilities indicates that these events typically represent the highest risk in terms of likelihood and consequence.

\subsection{Dose Assessment Methodology}

The unmitigated dose analyses for the DBAs are summarized in the following subsections and are based on the following dose assessment methodology that considers the transport of radiologic material via the air pathway to downwind receptors. The methodology uses a simple Gaussian plume model to represent transport and standard dose factors to convert the source term to radiologic impacts. Parameters for the transport model are discussed first, followed by those necessary to parameterize the equation for committed effective dose. 


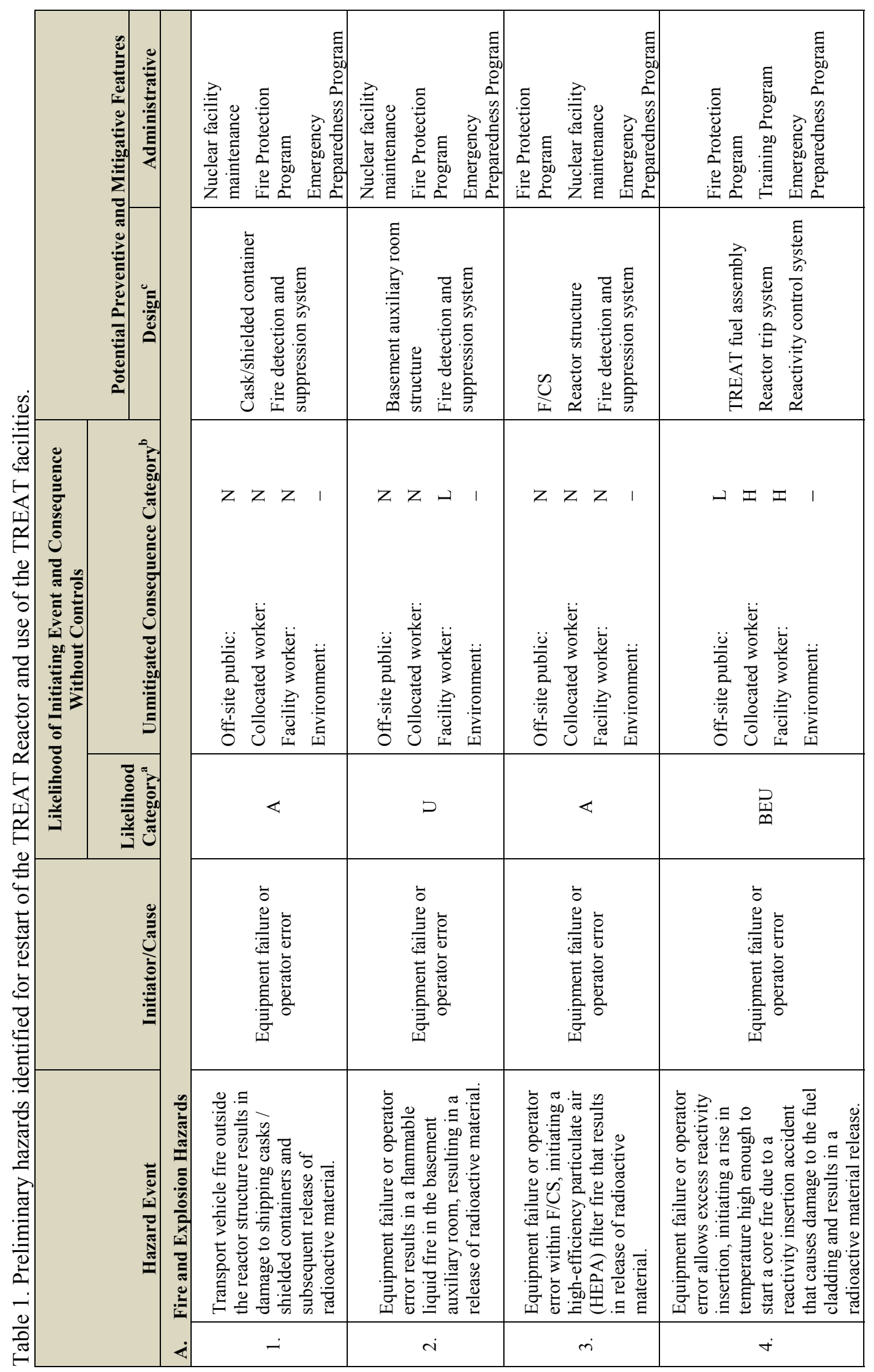




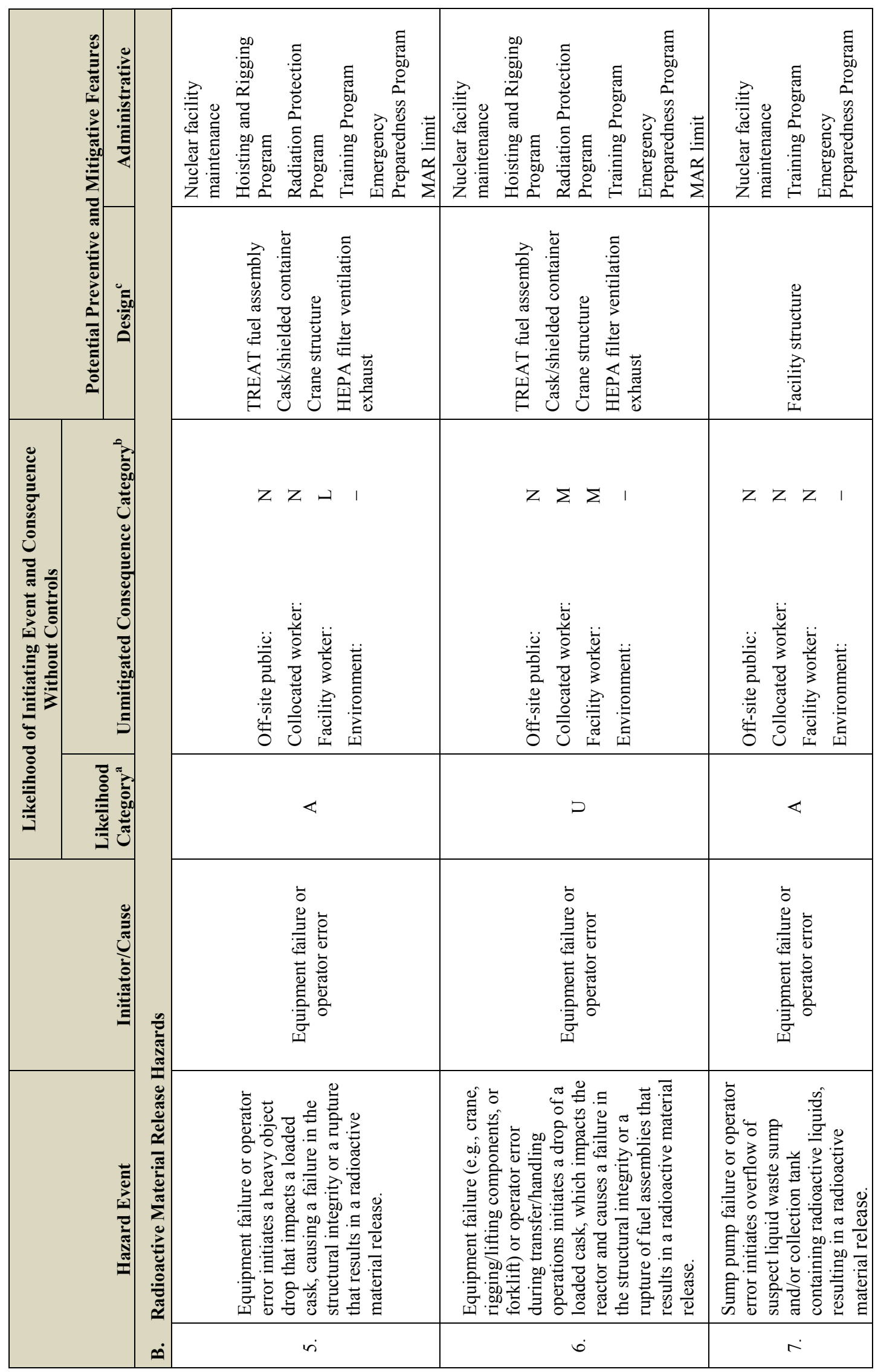




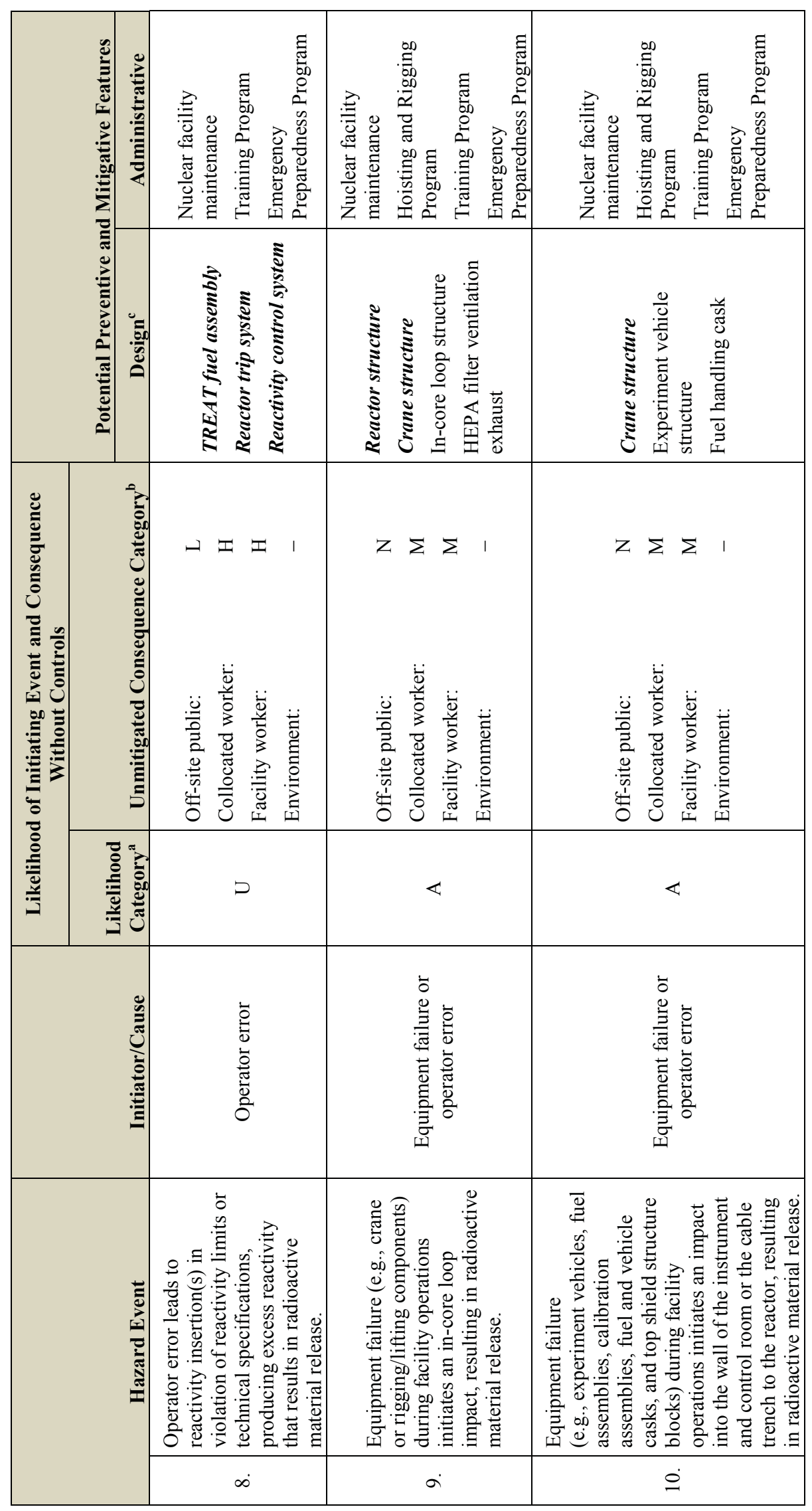




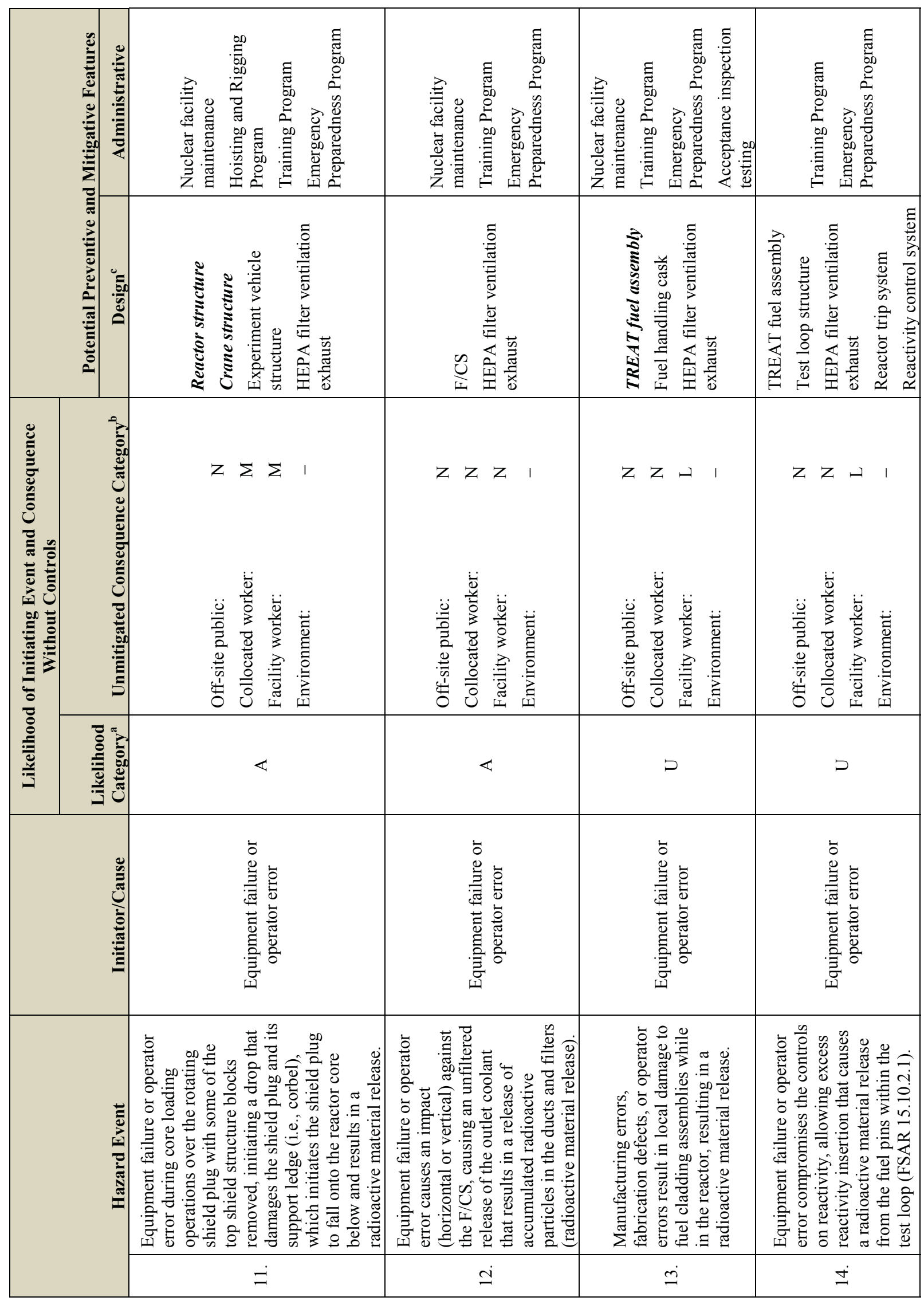




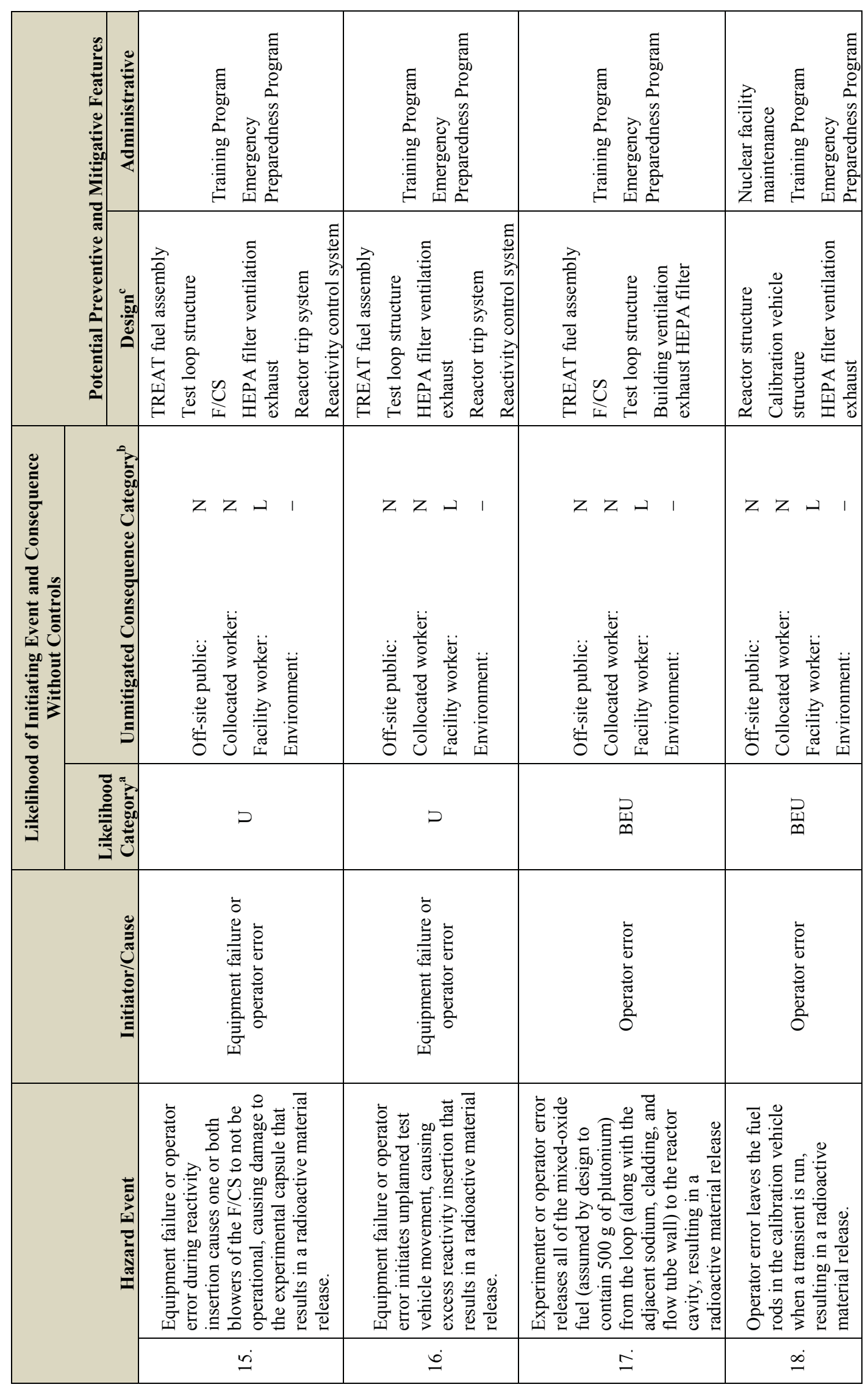




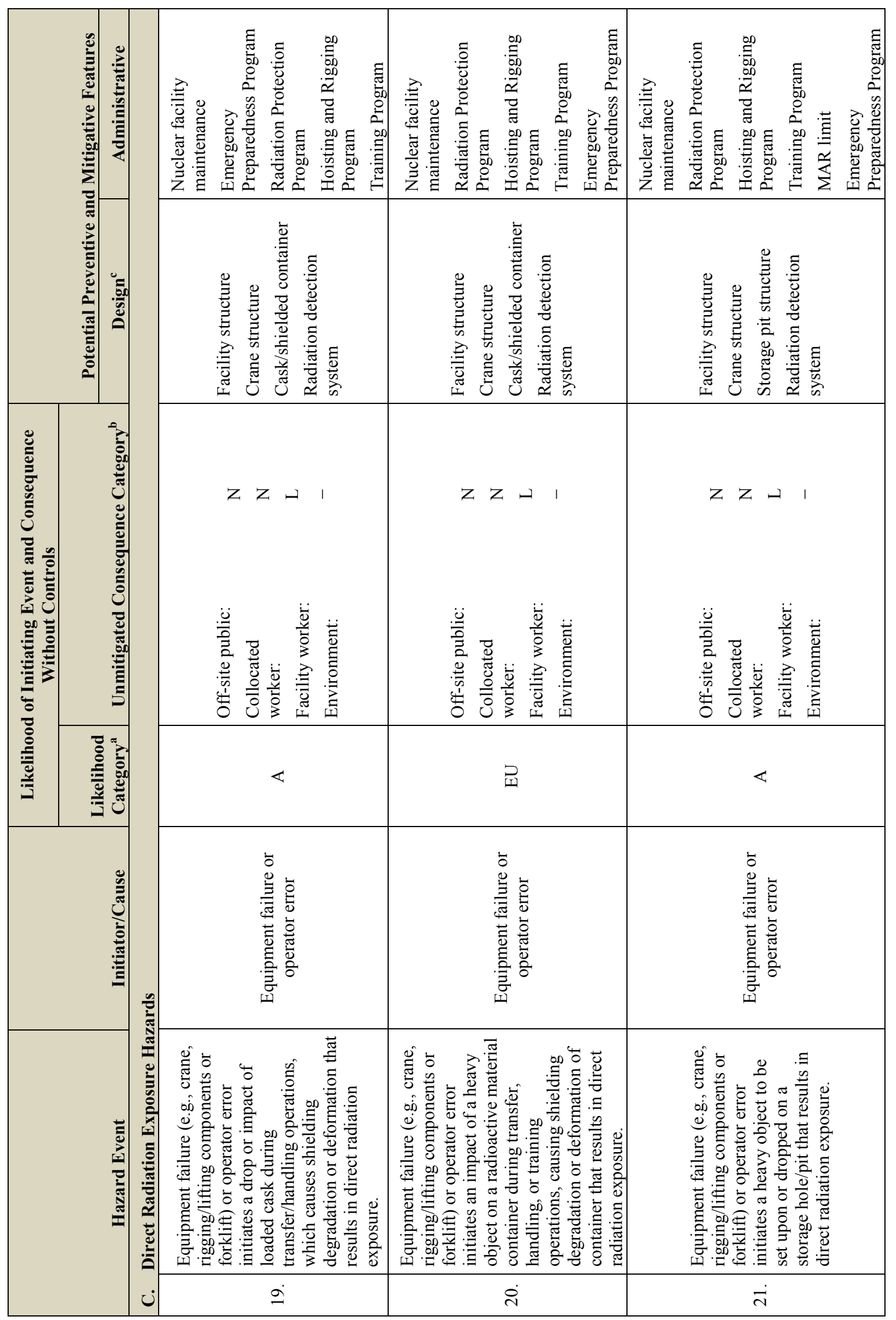




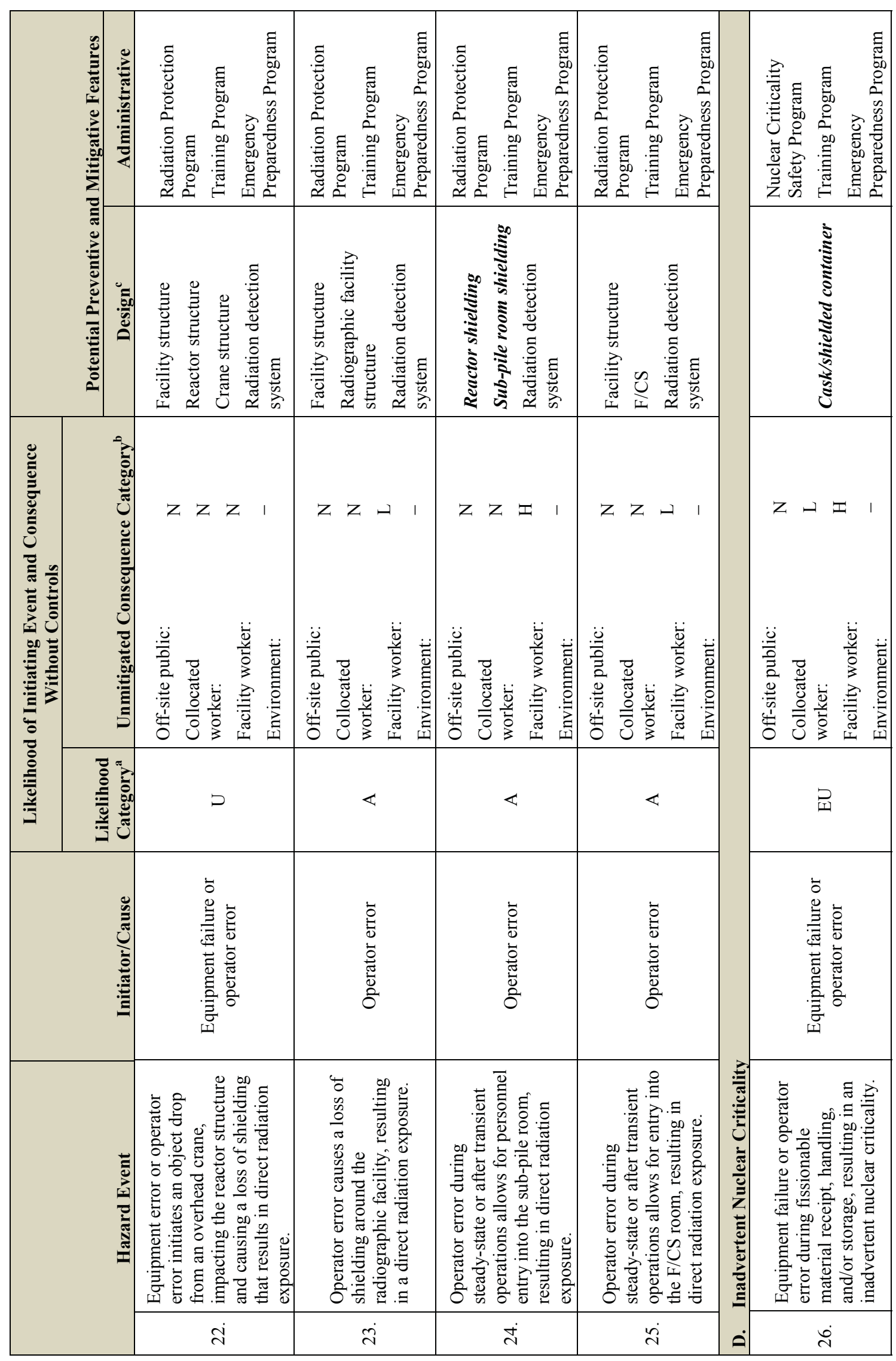




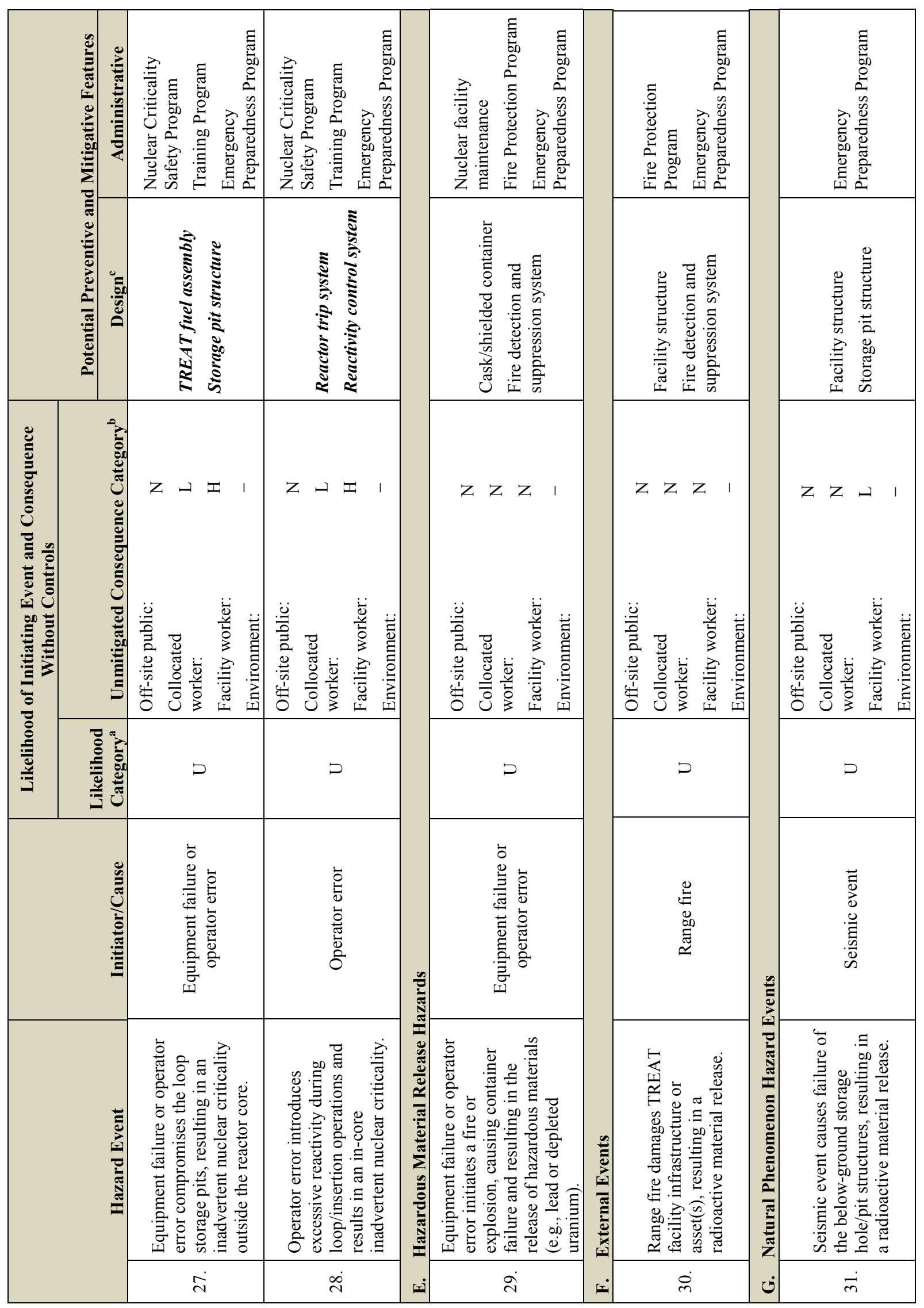




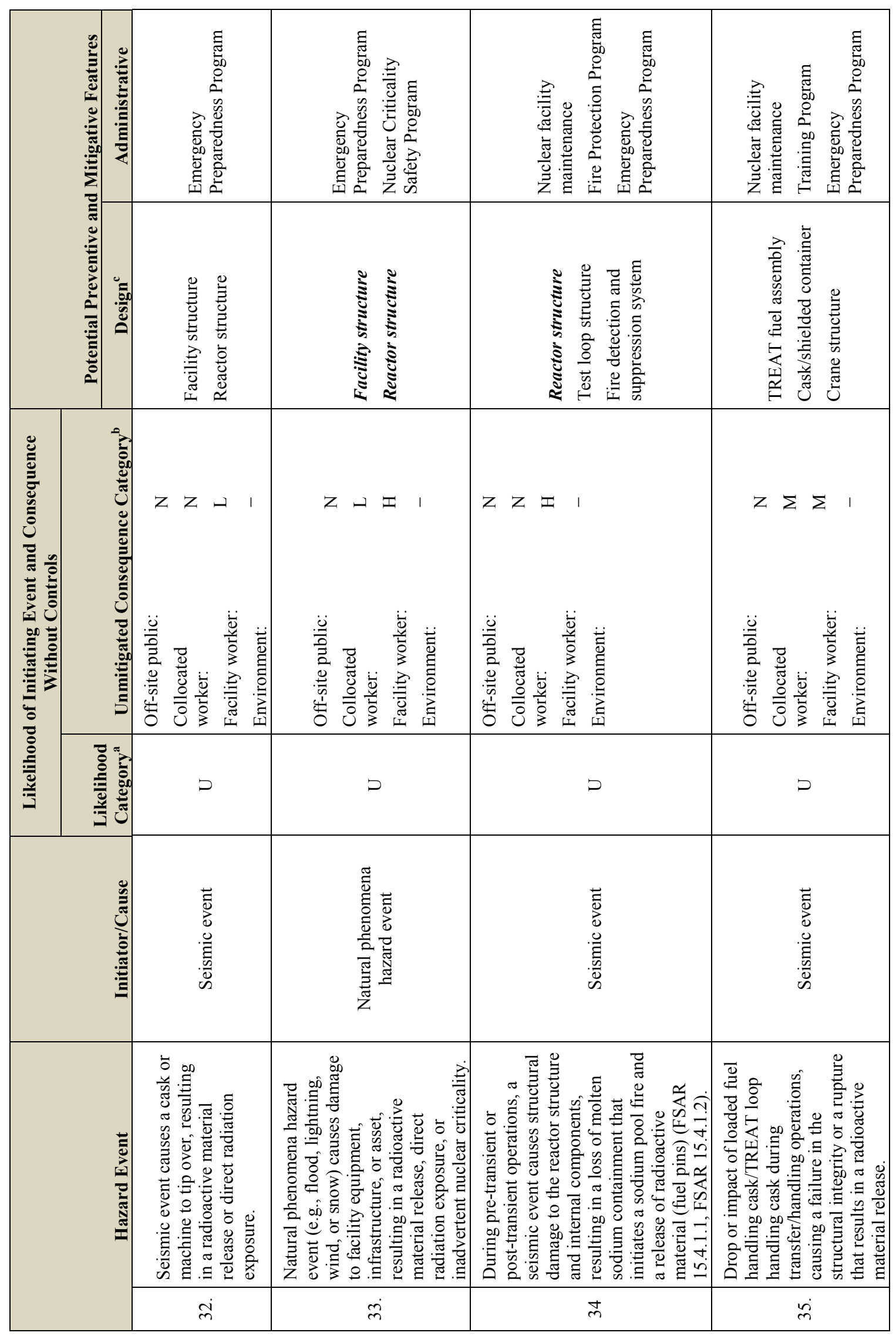




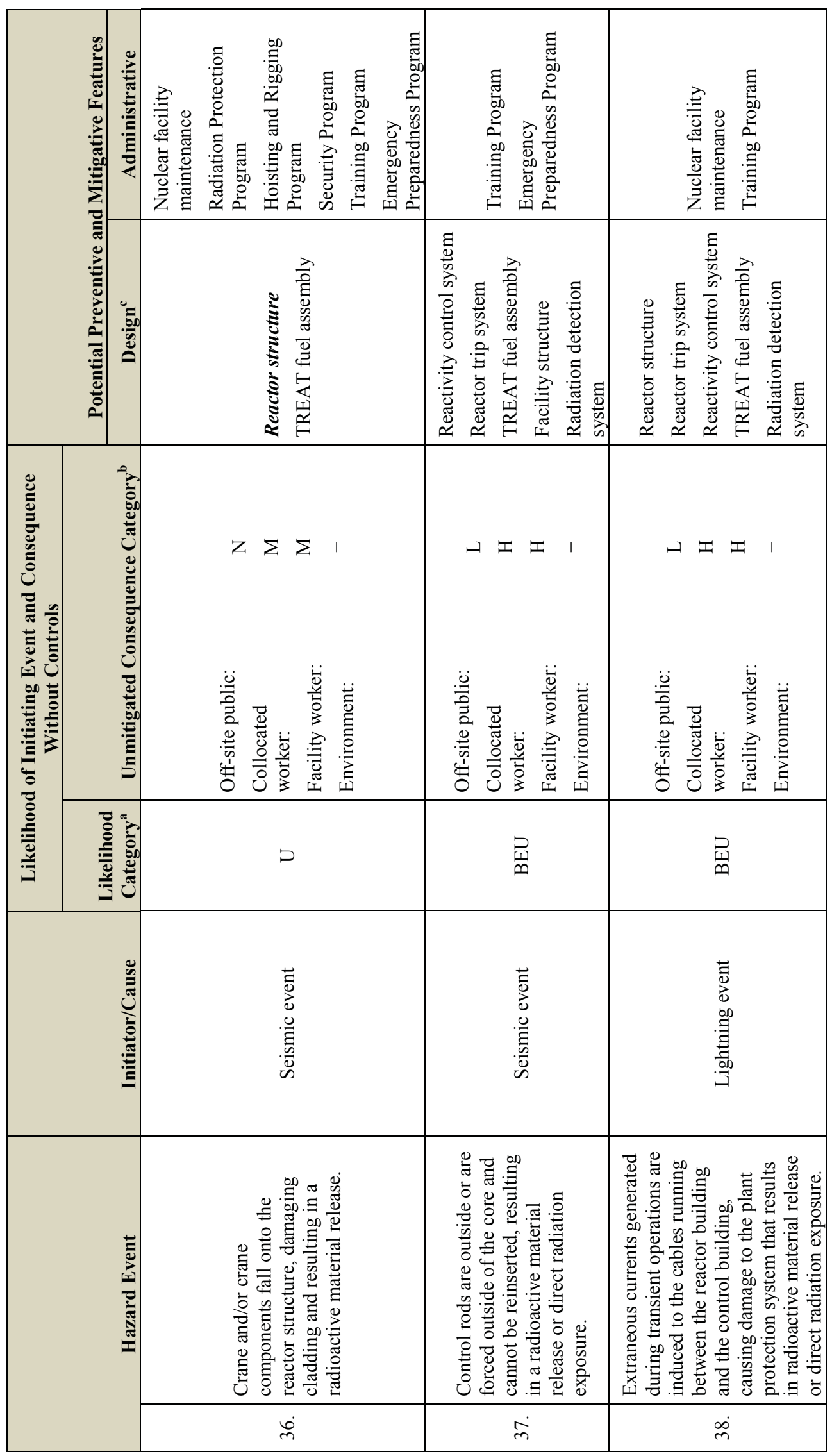




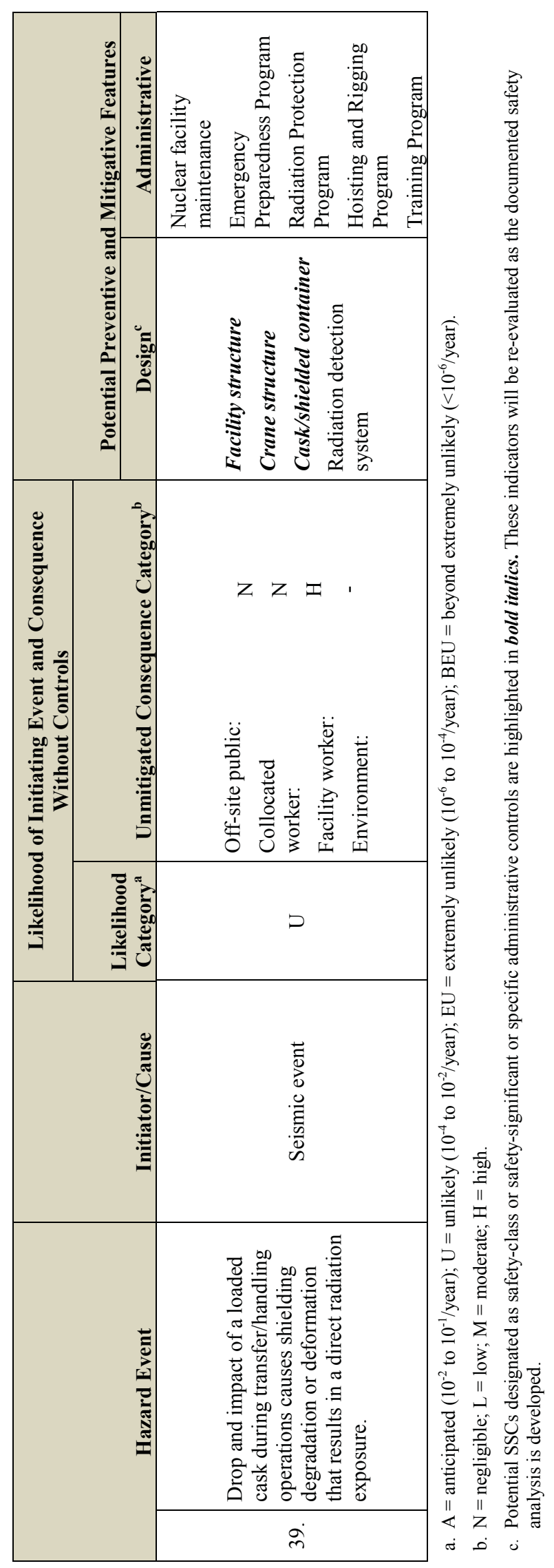


The transport model requires an estimation of the inventory or material at risk (MAR), damage ratio (DR), airborne release fraction (ARF), respirable fraction (RF), and leak path factor (LPF) in order to determine the airborne source term (ST). These factors and the values of the factors are explained and presented in "Airborne Release Fraction/Rates and Respirable Fractions for Nonreactor Nuclear Facilities" (DOE-HDBK-3010-94) and in "Alternative Radiological Source Terms for Evaluating Design Basis Accidents at Nuclear Power Reactors" (Regulatory Guide 1.183; NRC 2000). The five-factor formula from DOE-HDBK-3010-94 for estimating the ST is as follows:

$S T=M A R \times D R \times A R F \times R F \times L P F$

where:

ST = the airborne source term: the initial source term and initial respirable source term are products of the DR, ARF, and RF. A depleted source term after a subsequent stage of deposition or filtration is a product of the initial source term multiplied by the leak path factor of the specific stage.

MAR = material at risk: the amount of radioactive materials (in grams or curies of activity for each radionuclide) available to be acted on by a given physical stress.

DR = damage ratio: As defined by DOE-HDBK-3010-94, the DR is the fraction of the MAR actually affected by a normal operation process or an event sequence. For example, for normal operations involving nuclear fuel, the Nuclear Regulatory Commission Interim Safety Guide-5 (NRC 2003, Attachment, p. 7) recommends a value for a fuel rod breakage percentage of $1 \%$, with a corresponding DR during normal operations of 0.01 . During offnormal (accident conditions), the recommended fuel rod breakage percentage is $10 \%$ and the recommended DR is 0.1 .

$\mathrm{ARF}=$ airborne release fraction: the coefficient used to estimate the amount of a radioactive material that can be suspended in air as an aerosol and made available for airborne transport under a specific set of induced physical stresses. ARF is specific to the series of events and situations that are completed during the course of a potential release.

$\mathrm{RF}=$ respirable fraction: the fraction of airborne radionuclides as particles that can be transported through air and inhaled into the human respiratory system; it is assumed to include particles that are $10-\mu \mathrm{m}$ aerodynamic equivalent diameter and less.

$\mathrm{LPF}=$ leak path factor: the fraction of airborne materials transported from containment or confinement deposition or filtration mechanism (e.g., fraction of airborne material in a glove box leaving the glove box under static conditions or fraction of material passing through a HEPA filter).

The committed effective dose (CED) for downwind receptors, which include collocated workers and members of the public, is estimated from the following:

$C E D=S T \times \chi / Q \times B R \times D C F \times D C$

where:

$\chi / \mathrm{Q}=$ airborne dispersion values: the $\chi / \mathrm{Q}$ values for downwind distances are site specific. For this analysis, $\chi / Q$ values were obtained from RSAC-7 modeling for instantaneous releases using 95 percentile meteorological conditions specific to INL as described in Radiological Safety Analysis Computer (RSAC) Program Version 7.2 Users' Manual (INL 2010). For ground-level, point source releases along the plume centerline, airborne dispersion values are inversely proportional to the wind speed $(\mathrm{U})$ and horizontal and vertical dispersivities $\left(\sigma_{\mathrm{y}}\right.$ and $\sigma_{z}$ ). In this conservative, screening level dose evaluation, the wind speed was assigned a value of $1.04 \mathrm{~m} / \mathrm{s}$ instead of the higher INL average wind speed of $4.3 \mathrm{~m} / \mathrm{sec}$. 
$\frac{\chi}{Q}=\frac{1}{\pi u \sigma_{y} \sigma_{z}}$

The $\chi / \mathrm{Q}$ values for INL are given in Table 2 . These were computed assuming the release occurs at ground level and atmospheric stability class F. These locations correspond to those for collocated workers, which are scenario dependent, and for members of the public, who are assumed to be located south of the INL boundary. The closer INL boundary distance is used for accidents occurring at MFC and the farther distance is used for accidents occurring at TREAT.

Table 2. INL $\chi / \mathrm{Q}$ values at various separation distances.

\begin{tabular}{|c|c|c|}
\hline Distance $(m)$ & $\chi / \mathrm{Q}$ value $\left(\mathrm{sec} / \mathrm{m}^{3}\right)$ & Potential receptor \\
\hline 100 & $4.08 \mathrm{E}-03$ & Collocated worker \\
\hline 300 & $1.21 \mathrm{E}-03$ & Collocated worker \\
\hline 770 & $3.87 \mathrm{E}-04$ & $\begin{array}{l}\text { Facility or collocated worker in TREAT reactor control } \\
\text { building }\end{array}$ \\
\hline 1,000 & $2.80 \mathrm{E}-04$ & Collocated worker \\
\hline 5,000 & 4.12E-05 & $\begin{array}{l}\text { Public (distance from the Hot Fuel Examination Facility to } \\
\text { INL boundary) }\end{array}$ \\
\hline 6,000 & $3.36 \mathrm{E}-05$ & Public (distance from TREAT to INL boundary) \\
\hline
\end{tabular}

$\mathrm{BR}=$ breathing rate: the assumed breathing rate, described in DOE Order 440.1B, "Worker Protection Program for DOE," is $3.33 \mathrm{E}-4 \mathrm{~m}^{3} / \mathrm{sec}$.

$\mathrm{DCF}=$ dose conversion factor: published in ICRP-68, "Dose Coefficients for Intakes of Radionuclides by Workers," for facility and collocated workers and ICRP-72, "Age-dependent Doses from Intakes of Radionuclides," for use in determining dose to members of the offsite public.

$\mathrm{DC}=$ deposition coefficients: used to include plume fallout. The deposition coefficients are $9.78 \mathrm{E}-01$ at $100 \mathrm{~m}$ and $9.03 \mathrm{E}-01$ at $6,000 \mathrm{~m}$, respectively.

Facility worker inhalation dose is estimated based on dispersion of airborne radioactive material into a volume of $16,000 \mathrm{~m}^{3}$, which is the volume of the TREAT (MFC-720) high bay. The resulting facility worker dose is expressed as:

$\mathrm{CED}=\frac{\mathrm{ST}}{16,000 \mathrm{~m}^{3}} \times 60 \mathrm{sec} / \mathrm{min} \times \mathrm{BR} \times \mathrm{DCF}$

The CED for facility workers located within the TREAT Reactor building is expressed in units of $\mathrm{rem} / \mathrm{min}$. This allows a facility worker inhalation dose to be estimated based on worker stay time, because workers are trained to evacuate the building in the event of a radioactive material release event. Once the workers have evacuated the building, the inhalation doses are significantly lower. In some of the accident scenarios, the facility worker could be located in the TREAT Reactor control building, which is approximately $770 \mathrm{~m}$ from the TREAT Reactor building. Facility worker doses in these scenarios are computed using Equation 2.

The inhalation and cloud gamma doses are calculated by RSAC using the finite plume model and the RSAC default decay time for the exponential decay function (labeled "Exposure Time" in the RSAC gamma dose output section) of zero seconds. The default time of zero seconds allows RSAC to determine the decay time necessary to result in $100 \%$ release.

Although a fire may be a longer duration event than other radioactive material releases, airborne dispersion is evaluated as discussed above for an instantaneous release. This is conservative because the airborne dispersion parameters for longer-duration events (such as fires with significant plume rise) are lower than those for instantaneous releases. 


\subsection{Consequence Interpretation}

Radiological risk is defined in terms of dose and likelihood of occurrence. In the hazards analysis that will be conducted to support the documented safety analysis, the radiological risk will be used to determine the need for safety SSCs for facility workers, collocated workers, and for the offsite public. In this document, the radiological risk will be used to illustrate whether or not DBAs have the potential to require SSCs. If it is clear that SSCs will be required, mitigation provided by the SSC could be accounted for in determination of dose and event likelihood in subsequent analyses. They are not accounted for in the following analyses. The radiological risk evaluation guidelines used at INL are shown in Table 3 (from GDE-10820). The consequence categories largely correspond to the U.S. Environmental Protection Agency-recommended emergency planning action guide levels.

Table 3. Idaho National Laboratory risk evaluation guidelines.

\begin{tabular}{lcc}
\multicolumn{1}{c}{ Event Likelihood } & $\begin{array}{c}\text { Collocated and } \\
\text { Facility Worker Consequences }\end{array}$ & Offsite Public Consequences \\
\hline Anticipated $\left(10^{-2}\right.$ to $10^{-1} /$ year $)$ & $5.0 \mathrm{rem}(\mathrm{L})$ & $0.5 \mathrm{rem}(\mathrm{L})$ \\
Unlikely $\left(10^{-4}\right.$ to $10^{-2} /$ year $)$ & $25 \mathrm{rem}(\mathrm{M})$ & $5 \mathrm{rem}(\mathrm{M})$ \\
Extremely unlikely $\left(10^{-6}\right.$ to $10^{-4} /$ year $)$ & $100 \mathrm{rem}(\mathrm{H})$ & $25 \mathrm{rem}(\mathrm{H})$ \\
\hline
\end{tabular}

\section{UNMITIGATED DESIGN BASIS ACCIDENT ANALYSES}

Based on the preliminary assignment of consequence category and likelihoods shown in Table 1, the following events were selected for analysis because they are the most representative, bounding, or unique potential accident events:

- Reactor fuel clad failure; this event bounds all reactivity insertion accidents

- Transport vehicle fire; this event bounds all fire and explosion events

- Test loop drop; this event bounds all material handling accidents that result in radioactive material release or direct radiation exposure events

- Inadvertent nuclear criticality

- Externally initiated events

- Impact to the core; this event bounds all scenarios involving reactor refueling events

- Drop impact to the core by the test loop; this event bounds all scenarios involving insertion or removal of the test loops from the reactor

- Sodium fire impacting the core and experiment; this event bounds all scenarios potentially resulting in an energetic release of material from the experiment that could impact the TREAT core.

\subsubsection{Fuel Clad Failure}

A fuel clad failure is most likely to provide the bounding dose consequence for operation of the TREAT Reactor. The event is postulated to initiate during an unexpected reactivity insertion event, resulting in temperatures that could be high enough to damage the fuel clad and release fission products from the TREAT core fuel assemblies. This evaluation considers that a portion of the reactor core is heated to a sufficiently high temperature to permit the release of $65 \%$ of the fission product inventory as fuel assembly boundaries (fuel cladding) are breached. The likelihood category of the potential initiating events is unlikely.

The MAR in this scenario includes the radionuclide inventory of the conservative TREAT core configuration (INL 2013, Appendix E). The unmitigated analysis for this event takes no credit for safety 
features that could mitigate the consequences. For the unmitigated analysis, the conservative TREAT core MAR is assumed to be the entire core inventory for a 20-year operating history (one week after it has ended), plus the inventory produced by the special testing program and an additional 2,500-MJ transient. The 20-year inventory is based on the assumption that for 20 years, the reactor core has been operated weekly at a steady-state power level of $120 \mathrm{~kW}$ for a period of 4 hours and has produced a 5,000-MJ transient. The number of transients $(1,040)$ during the 20 -year period is approximately $18 \%$ in excess of the number of transients estimated by the user community for the lifetime of the facility, and each transient is approximately $22 \%$ in excess of the $100 \%$ design energy transient of the reactor. The special testing program inventory is based on the assumption that for 33 and 1/3 days, the reactor has produced a 3,500-MJ transient once every 8 hours for a total of 100 transients. Values used to estimate the source term for uptake in this event are shown in Table 4.

Table 4. Release factors for a fuel clad failure caused by excessive reactivity, resulting in airborne releases.

\begin{tabular}{|c|c|c|c|c|c|c|}
\hline Radionuclide & DR & ARF & $\mathrm{RF}$ & LPF & $\mathrm{ADJ}^{\mathrm{a}}$ & Applicable Release Scenario \\
\hline $\begin{array}{l}\text { Noble gases and } \\
\text { halogens }\end{array}$ & $6.50 \mathrm{E}-01$ & $1.00 \mathrm{E}+00$ & $1.00 \mathrm{E}+00$ & $1.00 \mathrm{E}+00$ & $6.50 \mathrm{E}-01$ & $\begin{array}{l}\text { All materials in the gaseous } \\
\text { state can be transported and } \\
\text { inhaled }\end{array}$ \\
\hline Actinides & $6.50 \mathrm{E}-01$ & $5.00 \mathrm{E}-04$ & $5.00 \mathrm{E}-01$ & $1.00 \mathrm{E}+00$ & $1.63 \mathrm{E}-04$ & $\begin{array}{l}\text { Plutonium exposed to thermal } \\
\text { stress (DOE-HDBK-3010-94, } \\
\text { p. 4-2) }\end{array}$ \\
\hline $\begin{array}{l}\text { Uranium and } \\
\text { fission products }\end{array}$ & $6.50 \mathrm{E}-01$ & $1.00 \mathrm{E}-03$ & $1.00 \mathrm{E}+00$ & $1.00 \mathrm{E}+00$ & $6.50 \mathrm{E}-04$ & $\begin{array}{l}\text { Uranium metal exposed to } \\
\text { thermal stress (DOE-HDBK- } \\
\text { 3010-94, p. 4-3) }\end{array}$ \\
\hline
\end{tabular}

$\mathrm{DR}=0.65$ (based on engineering judgment of the amount of material in the region of the core impacted from a reactivity insertion accident).

$\mathrm{ARF}=$ Noble gases and halogens are assumed to be gaseous and available for transport. Values for actinides, uranium, and fission products are taken from DOE-HDBK-3010-94 and are applicable to noncombustible solids exposed to thermal stress.

$\mathrm{RF}=$ Noble gases and halogens are assumed to be gaseous and available for inhalation. Values for actinides, uranium, and fission products are taken from DOE-HDBK-3010-94 and are applicable to noncombustible solids exposed to thermal stress.

$\mathrm{LPF}=1.0$ (standard assumption for assessment of unmitigated consequences in DOE facilities and activities and is appropriate for a fuel clad failure event in an unconfined space).

$\mathrm{ADJ}=$ Net adjustment $=\mathrm{DR} * \mathrm{ARF} * \mathrm{RF} * \mathrm{LPF}$. This is provided for comparison between scenarios .

Using appropriate values for each factor give the inhalation and cloud gamma dose consequences shown in Table 5. The doses shown do not credit safety SSCs or administrative controls. Doses assume the facility worker is located in the TREAT Reactor building, which is unlikely.

Dose evaluation guidelines (EGs) for the public and facility workers are 5 and 25 rem, respectively, for unlikely event initiators. As shown in Table 5, the conservative screening dose does not exceed the EG for the public. The conservative screening dose EG for collocated workers is exceeded. The conservative screening dose for the facility worker exceeds the EGs for an unlikely event if they are located in the TREAT Reactor building. This event would only occur during transient testing or during the cool down period following a transient test. Therefore, the doses at $770 \mathrm{~m}$ are applicable for facility workers and collocated workers because they all would be located in the TREAT Reactor control 
building. This relocation qualifies as a specific administrative control. At $770 \mathrm{~m}$, doses relative to those shown in Table 5 would be reduced by specific administrative controls that could be enforced to mitigate the consequences of such an accident, which could include evacuation from the TREAT Reactor control building.

Table 5. Conservative screening doses for fuel clad failure.

\begin{tabular}{ccccccc}
\hline & & \multicolumn{2}{c}{ Collocated Worker (rem) } & $\begin{array}{c}\text { Offsite Public } \\
\text { at 6,000 m } \\
\text { (rem) }\end{array}$ \\
\hline \multirow{2}{*}{$\begin{array}{c}\text { Core } \\
\text { inventory }\end{array}$} & Source & $\begin{array}{c}\text { Facility Worker } \\
\text { (rem/min) }\end{array}$ & At $100 \mathrm{~m}$ & At $300 \mathrm{~m}$ & At 770 m & $9.2 \mathrm{E}-01$ \\
& Cloud gamma & $5.1 \mathrm{E}+01$ & $1.8 \mathrm{E}+02$ & $5.3 \mathrm{E}+01$ & $1.7 \mathrm{E}+01$ & $6.8 \mathrm{E}-02$ \\
& Total & - & $1.1 \mathrm{E}+02$ & $3.3 \mathrm{E}+01$ & $1.0 \mathrm{E}+01$ & $9.9 \mathrm{E}-01$ \\
\hline
\end{tabular}

\subsubsection{Transport Vehicle Fire}

The lifting and handling of shipping containers requires the use of a transport vehicle. These vehicles introduce the potential for a vehicle fire that is postulated to occur during transport or during transfer container loading/unloading operations. The assessment of dose consequences assumes that a transport vehicle fire is caused by a fuel leak and ignition, resulting in a breach of the experiment test loop transfer cask. This evaluation only considers material that is affected by thermal stresses from the fire as the transfer cask boundaries are breached. The likelihood category of the initiating event is anticipated.

The MAR in this scenario is the bounding radionuclide inventory of the experiment assembly (INL 2013, Appendix E). The unmitigated analysis for this event takes no credit for safety features that could mitigate the consequences. For the unmitigated analysis, the experiment test loop MAR is assumed to be the contents of $2.7 \mathrm{~kg}$ ( 7 advanced oxide pins) of mixed oxide $\left(75 \% \mathrm{UO}_{2}-25 \% \mathrm{PuO}_{2}\right)$ at a burn-up level of $9 \%$, then allowed to decay for 1 year as discussed in TEV-1832, "Overview of Anticipated Transient Test Experiments." Values used to estimate the source term for uptake in this event are shown in Table 6.

Table 6. Release factors for airborne releases from a transport vehicle fire.

\begin{tabular}{lcccccc}
\hline \multicolumn{1}{c}{ Radionuclide } & DR & ARF & RF & LPF & ADJ & Applicable Release Scenario \\
\hline $\begin{array}{l}\text { Noble gases and } \\
\text { halogens }\end{array}$ & $1.00 \mathrm{E}-01$ & $1.00 \mathrm{E}+00$ & $1.00 \mathrm{E}+00$ & $1.00 \mathrm{E}+00$ & $1.00 \mathrm{E}-01$ & $\begin{array}{l}\text { All materials in the gaseous } \\
\text { state can be transported and } \\
\text { inhaled }\end{array}$ \\
Actinides & $1.00 \mathrm{E}-01$ & $5.00 \mathrm{E}-04$ & $5.00 \mathrm{E}-01$ & $1.00 \mathrm{E}+00$ & $2.50 \mathrm{E}-05$ & $\begin{array}{l}\text { Plutonium exposed to thermal } \\
\text { stress (DOE-HDBK-3010-94, } \\
\text { p. 4-2) }\end{array}$ \\
& $1.00 \mathrm{E}-01$ & $1.00 \mathrm{E}-03$ & $1.00 \mathrm{E}+00$ & $1.00 \mathrm{E}+00$ & $1.00 \mathrm{E}-04$ & $\begin{array}{l}\text { Uranium metal exposed to } \\
\text { thermal stress } \\
\text { (DOE-HDBK-3010-94, p. 4-3) }\end{array}$ \\
$\begin{array}{l}\text { Uranium and } \\
\text { fission products }\end{array}$ & & & & & &
\end{tabular}

$\mathrm{DR}=0.1$ (based on engineering judgment of the amount of material impacted from an engulfing fire, where the source material contains low amounts of combustibles and originates within multiple layers of protection).

$\mathrm{ARF}=$ Noble gases and halogens are assumed to be gaseous and available for transport. Actinides, uranium, and fission products are taken from DOE-HDBK-3010-94 and are applicable to noncombustible solids exposed to thermal stress. 
$\mathrm{RF}=$ Noble gases and halogens are assumed to be gaseous and available for inhalation. Actinides, uranium, and fission products are taken from DOE-HDBK-3010-94 and are applicable to noncombustible solids exposed to thermal stress.

$\mathrm{LPF}=1.0$ (standard assumption for DOE facilities and activities and is appropriate for a fire event in an unconfined space).

$\mathrm{ADJ}=$ Net adjustment $=\mathrm{DR} * \mathrm{ARF} * \mathrm{RF} * \mathrm{LPF}$.

Using the appropriate values for each factor give the inhalation and cloud gamma dose consequences shown in Table 7.

Table 7. Conservative screening doses for a transport vehicle fire.

\begin{tabular}{|c|c|c|c|c|c|c|}
\hline \multirow[b]{2}{*}{ MAR } & \multirow[b]{2}{*}{ Source } & \multirow{2}{*}{$\begin{array}{c}\text { Facility Worker } \\
\text { (rem/min) }\end{array}$} & \multicolumn{3}{|c|}{ Collocated Worker (rem) } & \multirow{2}{*}{$\begin{array}{c}\text { Offsite Public at } \\
6,000 \mathrm{~m} \\
\text { (rem) }\end{array}$} \\
\hline & & & At $100 \mathrm{~m}$ & At $300 \mathrm{~m}$ & At $770 \mathrm{~m}$ & \\
\hline \multirow{3}{*}{$\begin{array}{l}\text { Test loop } \\
\text { inventory }\end{array}$} & CED & $3.9 \mathrm{E}-02$ & $1.0 \mathrm{E}-01$ & $3.0 \mathrm{E}-02$ & $9.5 \mathrm{E}-03$ & $1.2 \mathrm{E}-03$ \\
\hline & Cloud gamma & - & $5.7 \mathrm{E}-06$ & $1.7 \mathrm{E}-06$ & $5.4 \mathrm{E}-07$ & $1.8 \mathrm{E}-07$ \\
\hline & Total & $3.9 \mathrm{E}-02$ & $1.0 \mathrm{E}-01$ & $3.0 \mathrm{E}-02$ & $9.5 \mathrm{E}-03$ & $1.2 \mathrm{E}-03$ \\
\hline
\end{tabular}

Dose consequence EGs for the public and collocated and facility workers are 0.5 and 5 rem, respectively, for anticipated events. As shown in Table 7, the conservative screening doses do not exceed the EG for the public, collocated workers, or facility workers. No controls would be needed to protect the public and workers and none have been credited in this analysis.

\subsubsection{Test Loop Drop}

This scenario evaluates the consequences of a radioactive material release that could result if a test loop is breached accidentally. This could occur if the test loop were to be severely impacted by an object or if the loop impacted a stationary object during transfer. The severe impact is most likely initiated by a failure of the reactor building crane or of the reactor building structures supporting the crane during loop handling operations. Crane failures could result from structural/mechanical failures, electrical failures, and operator errors; it is assumed that the reactor building support structure could fail during an earthquake. The impact is assumed to cause a total breach of all fuel containment barriers. Depending on whether a loop or a test train is involved and whether the accident occurs before or after the experiment transient, these barriers could consist of one of the casks, the loop secondary vessel, the loop primary vessel, the security can, or the fuel pin cladding. The likelihood categories for initiating events are unlikely for a seismically induced event and anticipated for an event initiated by operator error or mechanical failure.

The MAR in this scenario is the bounding radionuclide inventory for the experiment assembly. The unmitigated analysis for this event takes no credit for safety features that could mitigate the consequences. For the unmitigated analysis, the experimental test loop MAR is assumed to be the contents of $2.7 \mathrm{~kg}$ (7 advanced oxide pins) of mixed oxide $\left(75 \% \mathrm{UO}_{2}-25 \% \mathrm{PuO}_{2}\right)$ at a burnup level of $9 \%$ that is allowed to decay for 1 year. Values used to estimate the source term for uptake in this event are shown in Table 8.

$\mathrm{DR}=1.0$ (based on engineering judgment of the amount of material impacted from a test loop impact).

$\mathrm{ARF}=$ Noble gases and halogens are assumed to be gaseous and available for transport. Actinides, uranium, and fission products are taken from DOE-HDBK-3010-94 and are applicable to the spill of powders, assuming that the energy of the event is sufficient to generate powder from the solid radioactive material. 
RF = Noble gases and halogens are assumed to be gaseous and available for inhalation. Actinides, uranium, and fission products are taken from DOE-HDBK-3010-94 and are applicable to the spill of powders, assuming that the energy of the event is sufficient to generate powder from the solid radioactive material.

$\mathrm{LPF}=1.0$ (standard assumption for DOE facilities and activities and is appropriate for an impaction event in an unconfined space).

$\mathrm{ADJ}=$ Net adjustment $=\mathrm{DR} * \mathrm{ARF} * \mathrm{RF} * \mathrm{LPF}$.

Table 8. Release factors for airborne releases from a test loop drop.

\begin{tabular}{lcccccc}
\hline \multicolumn{1}{c}{ Radionuclide } & DR & ARF & RF & LPF & ADJ & Applicable Release Scenario \\
\hline $\begin{array}{l}\text { Noble gases and } \\
\text { halogens }\end{array}$ & $1.00 \mathrm{E}+00$ & $1.00 \mathrm{E}+00$ & $1.00 \mathrm{E}+00$ & $1.00 \mathrm{E}+00$ & $1.00 \mathrm{E}+00$ & $\begin{array}{l}\text { All materials in the gaseous } \\
\text { state can be transported and } \\
\text { inhaled }\end{array}$ \\
$\begin{array}{l}\text { Actinides, } \\
\text { uranium, and } \\
\text { fission products }\end{array}$ & $1.00 \mathrm{E}+00$ & $2.00 \mathrm{E}-03$ & $3.00 \mathrm{E}-01$ & $1.00 \mathrm{E}+00$ & $6.00 \mathrm{E}-04$ & $\begin{array}{l}\text { Solids exposed to free-fall spill } \\
\text { and impaction stress } \\
\text { (DOE-HDBK-3010-94,p. 4-9) }\end{array}$ \\
\hline
\end{tabular}

Using appropriate values for each factor give the inhalation and cloud gamma dose consequences shown in Table 9.

Table 9. Conservative screening doses for a test loop drop.

\begin{tabular}{|c|c|c|c|c|c|c|}
\hline \multirow[b]{2}{*}{ MAR } & \multirow[b]{2}{*}{ Source } & \multirow{2}{*}{$\begin{array}{c}\text { Facility Worker } \\
\text { (rem/min) }\end{array}$} & \multicolumn{3}{|c|}{ Collocated Worker (rem) } & \multirow{2}{*}{$\begin{array}{c}\text { Offsite Public } \\
\text { at } 6,000 \mathrm{~m} \\
\text { (rem) }\end{array}$} \\
\hline & & & At $100 \mathrm{~m}$ & At $300 \mathrm{~m}$ & At $770 \mathrm{~m}$ & \\
\hline \multirow{3}{*}{$\begin{array}{l}\text { Test loop } \\
\text { inventory }\end{array}$} & CED & $2.5 \mathrm{E}+00$ & $8.8 \mathrm{E}+00$ & $2.6 \mathrm{E}+00$ & $8.3 \mathrm{E}-01$ & $2.5 \mathrm{E}-01$ \\
\hline & Cloud gamma & -1 & 1.1E-04 & $3.3 \mathrm{E}-05$ & $1.0 \mathrm{E}-05$ & $3.5 \mathrm{E}-06$ \\
\hline & Total & $2.5 \mathrm{E}+00$ & $8.8 \mathrm{E}+00$ & $2.6 \mathrm{E}+00$ & 8.3E-01 & $2.5 \mathrm{E}-01$ \\
\hline
\end{tabular}

Dose consequence EGs for the public and facility workers are 5 and 25 rem, respectively, for unlikely events and 0.5 and 5 rem for anticipated events. As shown in Table 9, the dose EG is not exceeded for the public. The conservative screening dose for facility workers could exceed the EG for an unlikely event when an exposure time is greater than about 10 minutes. The conservative screening dose for facility and collocated workers could exceed EGs for an anticipated event. Therefore, safety SSCs and/or specific administrative controls may be required as shown in Table 1 . However, they have not been credited in the screening level dose results shown in Table 9.

\subsubsection{Inadvertent Nuclear Criticality}

DBAs in this category include violations of mass, geometry, or moderation controls. If restart of the TREAT Reactor is selected as the preferred alternative, the nuclear criticality double contingency principle applicable to Hazard Category-2 facilities will be satisfied. This requires that two or more independent, concurrent, and unlikely upsets in process conditions must occur before an accidental nuclear criticality could occur. Evaluations will be conducted during development of the preliminary documented safety analysis to determine the need for criticality safety requirements (i.e., specific packaging configurations for high-fissile materials) pertaining to this facility.

\subsubsection{External Event}

Events in this category include plane crash, vehicle crash, and adjacent building fire/explosion. Plane crashes at INL are considered to be beyond extremely unlikely due to diversion of air traffic and based on 
air transportation safety information. Vehicle crashes and adjacent building fire/explosions will not have a significant impact on the radiologic sources at TREAT. Therefore, there is no anticipated release of radioactive material from this category of accidents should they occur.

\subsubsection{Impact (Natural Phenomena) to the Core}

This scenario considers the dose consequences following the impact of a fuel assembly that results from a failure of the reactor building crane or of the reactor building structures that support the crane during fuel handling operations. Crane failures could result from structural/mechanical failures, electrical failures, and operator errors; reactor building support structure failures are most likely to result from earthquakes. This accident could occur when the fuel assembly is over the core, over the fuel pit area, or over the floor area. The worst-case accident would be the drop of a fuel assembly over the core during insertion or removal, leading to the breach of the dropped fuel assembly and subsequent breaching of four surrounding fuel assemblies in the core. The radiological release consequences of the latter two cases are bounded by the first, with its five fuel assembly release. The impact is assumed to cause a total breach of all fuel containment barriers in the impacted core area. The likelihood categories of initiating events are unlikely for a seismically induced event and anticipated for an event initiated by operator error or mechanical failure.

The MAR in this scenario consists of the radionuclide inventory from five TREAT fuel assemblies, with the fuel assemblies corresponding to the conservative core configuration (INL 2013, Appendix E). The unmitigated analysis for this event takes no credit for safety features that could mitigate the consequences. For the unmitigated analysis, the five fuel assemblies are considered to be 5\% of the entire core inventory for a 20-year operating history (one week after it has ended), plus the inventory produced by the special testing program and an additional 2,500-MJ transient. The 20 -year inventory is based on the conservative assumptions that for 20 years, the reactor core has been operated weekly at a steady-state power level of $120 \mathrm{~kW}$ for a period of 4 hours and has produced a 5,000-MJ transient. The number of transients $(1,040)$ during the 20 -year period is approximately $18 \%$ in excess of the number of transients estimated by the user community for the lifetime of the facility, and each transient is approximately $22 \%$ in excess of the $100 \%$ design energy transient of the reactor. The special testing program inventory is based on the conservative assumptions that for 33 and 1/3 days the reactor has produced a 3,500-MJ transient once every 8 hours for a total of 100 transients. Values used to estimate the source term for uptake in this event are shown in Table 10.

Table 10. Release factors for airborne releases from a seismic event.

\begin{tabular}{lcccccl}
\hline \multicolumn{1}{c}{ Radionuclide } & DR & ARF & RF & LPF & ADJ & Applicable Release Scenario \\
\hline $\begin{array}{l}\text { Noble gases } \\
\text { halogens }\end{array}$ & $1.00 \mathrm{E}+00$ & $1.00 \mathrm{E}+00$ & $1.00 \mathrm{E}+00$ & $1.00 \mathrm{E}+00$ & $1.00 \mathrm{E}+00$ & $\begin{array}{l}\text { All materials in the gaseous } \\
\text { state can be transported and } \\
\text { inhaled }\end{array}$ \\
$\begin{array}{l}\text { Actinides, } \\
\text { uranium, and } \\
\text { fission products }\end{array}$ & $1.00 \mathrm{E}+00$ & $2.00 \mathrm{E}-03$ & $3.00 \mathrm{E}-01$ & $1.00 \mathrm{E}+00$ & $6.00 \mathrm{E}-04$ & $\begin{array}{l}\text { Solids exposed to free-fall } \\
\text { spill and impaction stress } \\
\text { (DOE-HDBK-3010-94, } \\
\text { p. 4-9) }\end{array}$ \\
\hline
\end{tabular}

$\mathrm{DR}=1.0$ (based on engineering judgment of the amount of material released from a fuel assembly impact, resulting in a breach of all fuel containment barriers).

$\mathrm{ARF}=$ Noble gases and halogens are assumed to be gaseous and available for transport. Actinides, uranium, and fission products are taken from DOE-HDBK-3010-94 and are applicable to the spill of powders, assuming the energy of the event is sufficient to generate powder from the solid radioactive material. 
RF = Noble gases and halogens are assumed to be gaseous and available for inhalation. Actinides, uranium, and fission products are taken from DOE-HDBK-3010-94 and are applicable to the spill of powders, assuming the energy of the event is sufficient to generate powder from the solid radioactive material.

$\mathrm{LPF}=1.0$ (standard assumption for DOE facilities and activities and is appropriate for an impaction event in an unconfined space).

$\mathrm{ADJ}=$ Net adjustment $=\mathrm{DR} * \mathrm{ARF} * \mathrm{RF} * \mathrm{LPF}$.

Using appropriate values for each factor give the inhalation and cloud gamma dose consequences shown in Table 11.

Table 11. Conservative screening doses for an impact to the TREAT Reactor core.

\begin{tabular}{ccccccc}
\hline & & $\begin{array}{c}\text { Facility } \\
\text { Worker } \\
\text { MAR }\end{array}$ & Source & \multicolumn{2}{c}{ Collocated Worker (rem) } & $\begin{array}{c}\text { Offsite Public } \\
\text { at } 6,000 \mathrm{~m} \\
\text { (rem) }\end{array}$ \\
Five fuel & CED & $3.9 \mathrm{E}+00$ & $1.4 \mathrm{E}+01$ & $4.2 \mathrm{E}+00$ & $1.3 \mathrm{E}+00$ & $7.0 \mathrm{E}-02$ \\
assemblies & Cloud gamma & - & $8.7 \mathrm{E}+00$ & $2.6 \mathrm{E}+00$ & $8.3 \mathrm{E}-01$ & $5.3 \mathrm{E}-03$ \\
& Total & $3.9 \mathrm{E}+00$ & $2.3 \mathrm{E}+01$ & $6.7 \mathrm{E}+00$ & $2.2 \mathrm{E}+00$ & $7.5 \mathrm{E}-02$ \\
\hline
\end{tabular}

Dose consequence EGs for the public and facility workers are 5 and 25 rem, respectively, for unlikely events. As shown in Table 11, the conservative screening doses do not exceed the EGs for the public. The EG for collocated workers is not exceeded at $100 \mathrm{~m}$. The conservative screening doses for a facility worker could exceed the EG for this unlikely event for exposure times greater than about 6.5 minutes. The conservative screening dose for facility and collocated workers do exceed the EG for an anticipated event. Therefore, safety SSCs and/or specific administrative controls may be required as shown in Table 1. However, they have not been credited in the screening level dose results shown in Table 11.

\subsubsection{Drop Impact to the Core and Experiment}

This scenario considers the dose consequences following an impact to TREAT Reactor fuel assemblies as the experiment assembly is being inserted or removed from the reactor. As with a TREAT Reactor fuel insertion accident, this scenario could result from a failure of the reactor building crane or of the reactor building structures supporting the crane during experiment handling operations over the reactor. Requirements for this scenario include (1) the experiment is in or being inserted into the core, (2) the crane is above the core and experiment, and (3) the crane fails. Crane failures could result from structural/mechanical failures, electrical failures, and operator errors; reactor building support structure failures could result from earthquakes. The impact is assumed to cause a total breach of fuel containment barriers in the impacted area and all experiment fuel barriers. Depending on whether a loop or a test train is involved and whether the accident occurs before or after the experiment transient, barriers protecting the experiment could consist of one of the casks, the loop secondary vessel, the loop primary vessel, the security can, or the fuel pin cladding; for the reactor fuel assemblies, barriers could consist of the fuel cladding.

The likelihood category of the initiation of a seismically induced event is unlikely and it the category is anticipated for an event initiated by operator error or mechanical failure. The unmitigated analysis for this event takes no credit for safety features that could mitigate the consequences.

The MAR in this scenario consists of the radionuclide inventory of five potentially damaged TREAT fuel assemblies, with the fuel assemblies corresponding to the conservative core configuration plus the bounding inventory of the experiment as follows: 
- The MAR for the five fuel assemblies is taken from the entire conservative core configuration inventory (INL 2013, Appendix E) for a 20-year operating history (one week after it has ended), plus the inventory produced by the special testing program and an additional 2,500-MJ transient. The 20 -year inventory is based on the conservative assumptions that for 20 years, the reactor core has been operated weekly at a steady-state power level of $120 \mathrm{~kW}$ for a period of 4 hours and has produced a 5,000-MJ transient. The number of transients $(1,040)$ during the 20 -year period is approximately $18 \%$ in excess of the number of transients estimated by the user community for the lifetime of the facility, and each transient is approximately $22 \%$ in excess of the $100 \%$ design energy transient of the reactor. The special testing program inventory is based on the conservative assumptions that for 33 and 1/3 days, the reactor has produced a 3,500-MJ transient once every 8 hours for a total of 100 transients.

- The MAR for the experimental test loop is assumed to be the contents of $2.7 \mathrm{~kg}$ ( 7 advanced oxide pins) of mixed oxide $\left(75 \% \mathrm{UO}_{2}-25 \% \mathrm{PuO}_{2}\right)$ at a burnup level of $9 \%$ that is allowed to decay for 1 year.

Values used to estimate the source term for uptake in this event are shown in Table 12. The factors are consistent with a drop scenario and differ from those for an incident including fire (Table 6). Fire is not expected to occur in this scenario, based on the following analysis:

- The total sodium contained in a MARK-III test loop is about $3.3 \mathrm{~kg}(3 \mathrm{~L})$. Before the test loop is removed from the core, the loop sodium is allowed to solidify (freeze) by cooling the test loop below the melting point $\left(97.8^{\circ} \mathrm{C}\right)$. The ignition temperature of sodium in the air depends on the area of surface exposed: vapor ignites at room temperature $\left(25^{\circ} \mathrm{C}\right)$; droplets at about $250^{\circ} \mathrm{F}\left(121^{\circ} \mathrm{C}\right)$; and an agitated pool at $400^{\circ} \mathrm{F}\left(204^{\circ} \mathrm{C}\right)$. As a result of sample decay heat, some of the sodium near the test fuel region may remain molten, suggesting that much less than $3.3 \mathrm{~kg}$ of sodium would be available to combust.

- For conservatism, we consider the complete oxidation of $3.3 \mathrm{~kg}$ of molten sodium. Given the enthalpy of sodium combustion $(828 \mathrm{~kJ} / \mathrm{mol})$ and the molecular weight $(62 \mathrm{~g} / \mathrm{mol})$, combusting $3.3 \mathrm{~kg}$ of sodium would release about $4.4 \mathrm{E}+07 \mathrm{~J}$.

- Heat sink effects will reduce the temperature of any released sodium. If the molten sodium contacts the metallic uranium or steel, the metal-sodium interface temperature will be at or below the sodium melting point. For loop rupture while the experiment is within the reactor, the steel in the experiment assembly and reactor, concrete making up the reactor structure, and uranium shielding will provide the heat sink.

- For the purposes of illustration, assume that the bulk temperature of $150^{\circ} \mathrm{C}$ is the temperature at which molten sodium would burn in a pool. This is between the combustion temperature for droplets and an agitated pool.

- The heat capacity of steel is $420 \mathrm{~J} / \mathrm{kg}^{\circ} \mathrm{C}$ and the density is $7.8 \mathrm{E}+03 \mathrm{~kg} / \mathrm{m}^{3}$.

- To raise the temperature from the bulk sodium temperature of 97.8 to $150^{\circ} \mathrm{C}\left(52.2^{\circ} \mathrm{C}\right)$, the required net heat sink capacity would be $6.99 \mathrm{E}+05 \mathrm{~J} /{ }^{\circ} \mathrm{C}$, corresponding to $2,000 \mathrm{~kg}$ of steel after applying the steel heat capacity.

- $\quad 2,000 \mathrm{~kg}$ of steel is equivalent to $0.26 \mathrm{~m}^{3}$, which when compared to the steel contained in the experiment assembly or reactor components is very small.

This shows that there is every expectation that any sodium released from the loop would solidify prior to catching fire. Therefore, catching the experiment fuel on fire is simply not likely to occur.

- Catching the reactor fuel or carbon on fire is even more remote given that it is difficult to achieve conditions for self-sustained combustion of graphite (NUREG/CR-4981 1987). If some small portion of the sodium were to catch fire, the reactor fuel fire would be diffusion limited, slowing the release of radionuclides from the fuel and resulting in lower peak air concentrations and effective dose. 
Table 12. Release factors for test loop plus reactor core airborne release.

\begin{tabular}{lcccccc}
\hline \multicolumn{1}{c}{ Radionuclide } & DR & ARF & RF & LPF & ADJ & Applicable Release Scenario \\
\hline $\begin{array}{l}\text { Noble gases } \\
\text { halogens }\end{array}$ & $1.00 \mathrm{E}+00$ & $1.00 \mathrm{E}+00$ & $1.00 \mathrm{E}+00$ & $1.00 \mathrm{E}+00$ & $1.00 \mathrm{E}+00$ & $\begin{array}{l}\text { All materials in the gaseous } \\
\text { state can be transported and } \\
\text { inhaled }\end{array}$ \\
$\begin{array}{l}\text { Actinides, } \\
\text { uranium, and } \\
\text { fission products }\end{array}$ & $1.00 \mathrm{E}+00$ & $2.00 \mathrm{E}-03$ & $3.00 \mathrm{E}-01$ & $1.00 \mathrm{E}+00$ & $6.00 \mathrm{E}-04$ & $\begin{array}{l}\text { Solids exposed to free-fall spill } \\
\text { and impaction stress } \\
\text { (DOE-HDBK-3010-94, p. 4-9) }\end{array}$ \\
\hline
\end{tabular}

$\mathrm{DR}=1.0$ (based on engineering judgment of the amount of material that could be released from a test loop impact on the reactor fuel assembly, resulting in a breach of all fuel containment barriers).

$\mathrm{ARF}=$ Noble gases and halogens are assumed to be gaseous and available for transport. Actinides, uranium, and fission products are taken from DOE-HDBK-3010-94 and are applicable to the spill of powders, assuming that the energy of the event is sufficient to generate powder from the solid radioactive material.

$\mathrm{RF}=$ Noble gases and halogens are assumed to be gaseous and available for inhalation. Actinides, uranium, and fission products are taken from DOE-HDBK-3010-94 and are applicable to the spill of powders, assuming that the energy of the event is sufficient to generate powder from the solid radioactive material.

$\mathrm{LPF}=1.0$ (standard assumption for DOE facilities and activities and is appropriate for an impaction event in an unconfined space).

ADJ $=$ Net adjustment $=\mathrm{DR}^{*} \mathrm{ARF} * \mathrm{RF} * \mathrm{LPF}$.

Using the values for each factor given in Table 12, the inhalation and cloud gamma dose consequences were computed as shown in Table 13.

Table 13. Conservative screening doses for impact of the reactor core by the experiment.

\begin{tabular}{|c|c|c|c|c|c|c|}
\hline \multirow[b]{2}{*}{ MAR } & \multirow[b]{2}{*}{ Source } & \multirow{2}{*}{$\begin{array}{l}\text { Facility Worker } \\
\text { (rem/min) }\end{array}$} & \multicolumn{3}{|c|}{ Collocated Worker (rem) } & \multirow{2}{*}{$\begin{array}{c}\text { Offsite Public } \\
\text { at } 6,000 \mathrm{~m} \\
\text { (rem) }\end{array}$} \\
\hline & & & At $100 \mathrm{~m}$ & At $300 \mathrm{~m}$ & At $770 \mathrm{~m}$ & \\
\hline \multirow[t]{3}{*}{ Core inventory } & CED & $3.9 \mathrm{E}+00$ & $1.4 \mathrm{E}+01$ & $4.2 \mathrm{E}+00$ & $1.3 \mathrm{E}+00$ & $7.0 \mathrm{E}-02$ \\
\hline & Cloud gamma & - & $8.7 \mathrm{E}+00$ & $2.6 \mathrm{E}+00$ & 8.3E-01 & $5.3 \mathrm{E}-03$ \\
\hline & Total & $3.9 \mathrm{E}+00$ & $2.3 \mathrm{E}+01$ & $6.7 \mathrm{E}+00$ & $2.2 \mathrm{E}+00$ & $7.5 \mathrm{E}-02$ \\
\hline \multirow{3}{*}{$\begin{array}{l}\text { Test loop } \\
\text { inventory }\end{array}$} & CED & $2.5 \mathrm{E}+00$ & $8.8 \mathrm{E}+00$ & $2.6 \mathrm{E}+00$ & 8.3E-01 & $2.5 \mathrm{E}-01$ \\
\hline & Cloud gamma & - & $1.1 \mathrm{E}-04$ & $3.3 \mathrm{E}-05$ & $1.0 \mathrm{E}-05$ & $3.5 \mathrm{E}-06$ \\
\hline & Total & $2.5 \mathrm{E}+00$ & $8.8 \mathrm{E}+00$ & $2.6 \mathrm{E}+00$ & 8.3E-01 & $2.5 \mathrm{E}-01$ \\
\hline \multirow[t]{3}{*}{ Total } & CED & $6.4 \mathrm{E}+00$ & $2.3 \mathrm{E}+01$ & $6.8 \mathrm{E}+00$ & $2.2 \mathrm{E}+00$ & $3.2 \mathrm{E}-01$ \\
\hline & Cloud gamma & - & $8.7 \mathrm{E}+00$ & $2.6 \mathrm{E}+00$ & 8.3E-01 & $5.3 \mathrm{E}-03$ \\
\hline & Total & $6.4 \mathrm{E}+00$ & $3.2 \mathrm{E}+01$ & $9.3 \mathrm{E}+00$ & $3.0 \mathrm{E}+00$ & 3.2E-01 \\
\hline
\end{tabular}

Dose consequence EGs for the public and facility workers are 5 and 25 rem, respectively, for unlikely events. As shown in Table 13, the conservative screening doses do not exceed the EGs for the public. The conservative screening doses for facility workers would exceed the EGs for an unlikely event when the exposure time is greater than 4 minutes. The conservative screening doses for collocated workers at $100 \mathrm{~m}$ also would exceed the EG, but collocated workers located further than about $300 \mathrm{~m}$ from the 
TREAT Reactor building would have adequate protection. Therefore, safety SSCs and/or specific administrative controls may be required as shown in Table 1 . However, they have not been credited in the screening level dose results shown in Table 13.

\subsubsection{Sodium Fire Impacting the Core and Experiment}

This scenario considers the dose consequences that could occur if the experiment assembly fails while it is inserted in the TREAT Reactor. The worst-case failure event would involve the $3 \mathrm{~L}(3.3 \mathrm{~kg}) \mathrm{of}$ sodium contained in the cooling loops. Contents of the sodium loop are designed to be contained at the maximum expected internal pressure and temperature (ANL 1979a, 1979b). However, it is possible that over-pressuring the experiment package could occur, initiated by (1) excessive heat, 2) loss of heat rejection capability, and (3) degradation/failure of the sodium loop in the experiment package. It also is possible that an accident could be initiated by an air-sodium reaction within the cooling loops caused by operator error or leaks of sealing surfaces (i.e., ports or flanges) of the experiment package.

Sodium self ignites in air at a range of 100 to $320^{\circ} \mathrm{C}$, depending on the physical circumstances (e.g., small static pool or agitated small pool) (SNL 2010) (Berkeley 1972). The maximum operating temperature of the TREAT Reactor is approximately $600^{\circ} \mathrm{C}$. If heat rejection in the experiment package is insufficient, allowing the internal temperature to rise above the self-ignition temperature, the liquid sodium in the cooling loop could burn in the presence of air. The sodium combustion reaction equations provided by Morewitz (1979) are:

Sodium Oxide Reaction: $4 \mathrm{Na}(\mathrm{l})+\mathrm{O}_{2}(\mathrm{~g}) \rightarrow 2 \mathrm{Na}_{2} \mathrm{O}(\mathrm{s})$

Sodium Peroxide Reaction: $2 \mathrm{Na}(\mathrm{l})+\mathrm{O}_{2}(\mathrm{~g}) \rightarrow \mathrm{Na}_{2} \mathrm{O}_{2}(\mathrm{~s})$

Sodium Hydroxide Reaction: $2 \mathrm{Na}(\mathrm{l})+2 \mathrm{H}_{2} \mathrm{O}(\mathrm{g}) \rightarrow 2 \mathrm{NaOH}+\mathrm{H}_{2}$

In the air-cooled TREAT Reactor, minimal water vapor would be expected and the production of sodium hydroxide would be unexpected. The sodium oxide reaction dominates the combustion reaction because most of the sodium reacted with the air produces $\mathrm{Na}_{2} \mathrm{O}$. However, higher energy release is associated with the production of sodium peroxide. The amount of sodium oxidized would depend on the availability of air within the sodium loops.

If the molten sodium is retained in the primary containment of the experiment loop, the availability of air would be limited to the amount not purged and replaced with inert gas as the experiment is assembled. Leakage of air into the experiment assembly will not occur because the internal inert gas pressure is higher than atmospheric. Therefore, the amount of sodium oxidized would be small and limited by the availability of air. The oxidation rate would be diffusion limited and would occur over a relatively long time period. It is likely that there would be no radiologic release from either the reactor core or experiment fuel.

If molten sodium is released from the primary containment into the secondary containment and the secondary containment holds, the oxidation process could be more rapid and the experiment assembly could become over pressurized, potentially damaging the fuel in the experiment and the surrounding reactor fuel elements. Release of molten sodium into the reactor cavity would be noted by the sensors and the reactor would be shutdown. Catching the reactor fuel or carbon on fire is unlikely given that it is difficult to achieve conditions for self-sustained combustion of graphite (NUREG/CR-4981 1987). If some small portion of the sodium were to catch fire, the reactor fuel fire would be diffusion limited, slowing the release of radionuclides from the fuel and resulting in lower peak air concentrations and effective dose.

The likelihood for this event historically has been mitigated by the design and construction requirements of the MARK-III test assembly and pre-testing prior to insertion into the reactor. Based on the 25-year transient testing history of TREAT, there has never been a loss of containment from an 
experiment. Therefore, the initiating event likelihood category is unlikely based on an estimated 500 tests during the operating history.

The MAR in this scenario consists of the radionuclide inventory of six TREAT fuel assemblies, which is determined by the space occupied by the sodium loop experiment while in the core plus the bounding inventory of the experiment as follows:

- The MAR for the six fuel assemblies is based on the area occupied by a sodium loop while in the core. The core inventory corresponds to that for a 20-year operating history (one week after it has ended), plus the inventory produced by the special testing program and an additional 2,500-MJ transient. The 20-year inventory is based on the conservative assumptions that for 20 years the reactor core has been operated weekly at a steady-state power level of $120 \mathrm{~kW}$ for a period of 4 hours and has produced a 5,000-MJ transient. The number of transients $(1,040)$ during the 20 -year period is approximately $18 \%$ in excess of the number of transients estimated by the user community for the lifetime of the facility, and each transient is approximately $22 \%$ in excess of the $100 \%$ design energy transient of the reactor. The special testing program inventory is based on the conservative assumptions that for 33 and $1 / 3$ days, the reactor has produced a 3,500-MJ transient once every 8 hours for a total of 100 transients.

The analysis assumes that fire ensues and affects the experiment fuel and reactor fuel. This is a conservative assumption and is not likely to occur for the following reasons:

- After the onset of combustion, the molten sodium will be released from the test assembly where it will cool on contact with the reactor components.

- Given the self-combustion temperature required to ignite the TREAT fuel (discussed in Section 4.1.7), an experiment fire is not expected to cause the TREAT fuel to burn.

Other values used to estimate the source term for uptake in this event are shown in Table 14. The ARF and RF factors for the experiment are consistent with an incident, including fire (Table 6); although based on event likelihood and the analysis provided for the accident in Section 3.2.7, fire is not expected to occur.

Table 14. Release factors for a sodium fire that results in airborne releases.

\begin{tabular}{llccccc} 
Radionuclide & \multicolumn{1}{c}{ DR } & ARF & RF & LPF & ADJ & $\begin{array}{c}\text { Applicable Release } \\
\text { Scenario }\end{array}$ \\
\hline $\begin{array}{l}\text { Noble gases } \\
\text { and halogens }\end{array}$ & $\begin{array}{l}\text { 6 assemblies in core } \\
100 \% \text { damage to } \\
\text { experiment }\end{array}$ & $1.00 \mathrm{E}+00$ & $1.00 \mathrm{E}+00$ & $1.00 \mathrm{E}+00$ & $1.00 \mathrm{E}+00$ & $\begin{array}{l}\text { All materials in the } \\
\text { gaseous state can be } \\
\text { transported and inhaled }\end{array}$ \\
Actinides & $\begin{array}{l}\text { 6 assemblies in core } \\
100 \% \text { damage to } \\
\text { experiment }\end{array}$ & $5.00 \mathrm{E}-04$ & $5.00 \mathrm{E}-01$ & $1.00 \mathrm{E}+00$ & $2.50 \mathrm{E}-04$ & $\begin{array}{l}\text { Plutonium exposed to } \\
\text { thermal stress } \\
\text { (DOE-HDBK-3010-94, } \\
\text { p. 4-2) }\end{array}$ \\
$\begin{array}{l}\text { Uranium and } \\
\text { fission } \\
\text { products }\end{array}$ & $\begin{array}{l}\text { 6 assemblies in core } \\
100 \% \text { damage to } \\
\text { experiment }\end{array}$ & $1.00 \mathrm{E}-03$ & $1.00 \mathrm{E}+00$ & $1.00 \mathrm{E}+00$ & $1.00 \mathrm{E}-03$ & $\begin{array}{l}\text { Uranium metal exposed } \\
\text { to thermal stress } \\
\text { (DOE-HDBK-3010-94, } \\
\text { p. 4-3) }\end{array}$ \\
\hline
\end{tabular}

$\mathrm{DR}=0.1$ (based on engineering judgment of the amount of material impacted from an engulfing fire, where the source material contains low amounts of combustibles and originates within multiple layers of protection). 
$\mathrm{ARF}=$ Noble gases and halogens are assumed to be gaseous and available for transport. Actinides, uranium, and fission products are taken from DOE-HDBK-3010-94 and are applicable to noncombustible solids exposed to thermal stress.

$\mathrm{RF}=$ Noble gases and halogens are assumed to be gaseous and available for inhalation. Actinides, uranium, and fission products are taken from DOE-HDBK-3010-94 and are applicable to noncombustible solids exposed to thermal stress.

$\mathrm{LPF}=1.0$ (standard assumption for DOE facilities and activities and is appropriate for a fire event in an unconfined space).

$\mathrm{ADJ}=$ Net adjustment $=\mathrm{DR} * \mathrm{ARF} * \mathrm{RF} * \mathrm{LPF}$.

Using the values for each factor given in Table 14, the inhalation and cloud gamma dose consequences were computed as shown in Table 15.

Table 15. Conservative screening doses for a sodium loop fire also impacting the reactor core.

\begin{tabular}{|c|c|c|c|c|c|c|}
\hline \multirow[b]{2}{*}{ MAR } & \multirow[b]{2}{*}{ Source } & \multirow{2}{*}{$\begin{array}{c}\text { Facility Worker } \\
\text { (rem/min) }\end{array}$} & \multicolumn{3}{|c|}{ Collocated Worker (rem) } & \multirow{2}{*}{$\begin{array}{l}\text { Offsite Public } \\
\text { at } 6,000 \mathrm{~m} \\
\text { (rem) }\end{array}$} \\
\hline & & & At $100 \mathrm{~m}$ & At $300 \mathrm{~m}$ & At $770 \mathrm{~m}$ & \\
\hline \multirow[t]{3}{*}{ Core inventory } & CED & $4.7 \mathrm{E}+00$ & $1.7 \mathrm{E}+01$ & $4.9 \mathrm{E}+00$ & $1.6 \mathrm{E}+00$ & $8.5 \mathrm{E}-02$ \\
\hline & Cloud gamma & - & $1.0 \mathrm{E}+01$ & $3.0 \mathrm{E}+00$ & $9.7 \mathrm{E}-01$ & $6.3 \mathrm{E}-03$ \\
\hline & Total & $4.7 \mathrm{E}+00$ & $2.7 \mathrm{E}+01$ & $7.9 \mathrm{E}+00$ & $2.5 \mathrm{E}+00$ & $9.1 \mathrm{E}-02$ \\
\hline \multirow{3}{*}{$\begin{array}{l}\text { Test loop } \\
\text { inventory }\end{array}$} & CED & $3.9 \mathrm{E}-01$ & $1.0 \mathrm{E}+00$ & $3.0 \mathrm{E}-01$ & $9.5 \mathrm{E}-02$ & $1.2 \mathrm{E}-02$ \\
\hline & Cloud gamma & - & $5.7 \mathrm{E}-05$ & $1.7 \mathrm{E}-05$ & $5.4 \mathrm{E}-06$ & $1.8 \mathrm{E}-06$ \\
\hline & Total & $3.9 \mathrm{E}-01$ & $1.0 \mathrm{E}+00$ & $3.0 \mathrm{E}-01$ & $9.5 \mathrm{E}-02$ & $1.2 \mathrm{E}-02$ \\
\hline \multirow[t]{3}{*}{ Total } & CED & $5.1 \mathrm{E}+00$ & $1.8 \mathrm{E}+01$ & $5.2 \mathrm{E}+00$ & $1.7 \mathrm{E}+00$ & $9.7 \mathrm{E}-02$ \\
\hline & Cloud gamma & - & $1.0 \mathrm{E}+01$ & $3.0 \mathrm{E}+00$ & $9.7 \mathrm{E}-01$ & $1.8 \mathrm{E}-02$ \\
\hline & Total & $5.1 \mathrm{E}+00$ & $2.8 \mathrm{E}+01$ & $8.2 \mathrm{E}+00$ & $2.6 \mathrm{E}+00$ & $1.2 \mathrm{E}-01$ \\
\hline
\end{tabular}

Dose consequence EGs for the public and facility workers are 5 and 25 rem, respectively, for unlikely events. As shown in Table 15, the conservative screening doses for members of the public do not exceed the EGs. The dose EG for a collocated worker at $100 \mathrm{~m}$ is exceeded for unlikely events. The screening level doses for facility workers could exceed the EGs for an unlikely event for exposure times greater than about 5 minutes. However, this event would only occur during transient testing or during the cool-down period following a transient test. Therefore, the doses at $770 \mathrm{~m}$ are applicable for facility workers and collocated workers because they all would be located in the TREAT Reactor control building. This relocation qualifies as a specific administrative control. At $770 \mathrm{~m}$, doses relative to the conservative screening doses could be reduced by other specific administrative controls not credited in this screening-level evaluation.

\section{REFERENCES}

10 CFR 830, "Nuclear Safety Management," Subpart B, "Safety Basis Requirements," Code of Federal Regulations, Office of the Federal Register, January 2001.

42 USC $\S 4321$ et seq., "National Environmental Policy Act of 1969 (NEPA)," United States Code, January 1970. 
ANL, 1979a, “37-Pin and 7-Pin Advanced TREAT Loop Title II Design Report Prepared for Argonne National Laboratory," Volume I, Prepared by AMETEK, Straza Division and Basic Technology Incorp. December 14, 1981, 8-530230.

ANL, 1979b, "System Design Description for MARK-III Loop Experiment Systems," R0250-1000-SA-02, Revision 2, Argonne National Laboratory.

Berkeley, 1972, “Central Electricity Generating Board," Research Department, RD/B/N2412, The Combustion of Liquid Sodium in Air, R. N. Newman, Berkeley Nuclear Laboratories, November 1972.

DOE, 2002, "Recommendations for Analyzing Accidents under the National Environmental Policy Act," U.S. Department of Energy, July 2002.

DOE-HDBK-3010-1994, “Airborne Release Fractions/Rates and Respirable Fractions for Nonreactor Nuclear Facilities," U.S. Department of Energy, Change Notice No. 1, March 2000.

DOE Order 440.1B, “Worker Protection Program for DOE,” U.S. Department of Energy, May 2007.

ECAR-2185, 2013, "Evaluation of Facility Inventory and Inhalation Dose Consequences for TREAT Basis for Interim Operations," Revision 0, DRAFT.

FSAR, 2009, “Transient Reactor Test Facility (TREAT) Final Safety Analysis Report,” S3942-0001-YT.

GDE-10820, 2012, “INL Guide to Safety Analysis Methodology,” Revision 0, Idaho National Laboratory, September 2012.

ICRP-68, 1994, "Dose Coefficients for Intakes of Radionuclides by Workers," International Commission on Radiological Protection.

ICRP-72, 1996, “Age-dependent Doses from Intakes of Radionuclides,” International Commission on Radiological Protection.

INL, 2010, Radiological Safety Analysis Computer (RSAC) Program Version 7.2 Users' Manual, INL/EXT-09-15275, Revision 1, Idaho National Laboratory, October 2010.

INL, 2013, Impacts Analysis Supporting the National Environmental Policy Act Environmental Assessment for the Resumption of Transient Testing Project, Idaho National Laboratory, July 2013.

Morewitz, H. A., 1979, “Sodium Spray Fires,” in Nuclear Engineering and Design, 42, 123-135.

NRC, 2000, Alternative Radiological Source Terms for Evaluating Design Basis Accidents at Nuclear Power Reactors, Regulatory Guide 1.183, U.S. Nuclear Regulatory Commission, Washington, D.C., July 2000.

NRC, 2003, "Interim Staff Guidance - 5, Revision 1. Confinement Evaluation," SFST-ISG-5, Revision 1, Washington, D.C.: U.S. Nuclear Regulatory Commission, accessed June 3, 2013 http://www.nrc.gov/reading-rm/doc-collections/isg/spent-fuel.html.

NUREG/CR-4981, 1987, “A safety Assessment of the Use of Graphite in Nuclear Reactors Licensed by the U.S. NRC.” 
SNL, 2010, Understanding Thermal Consequences of Liquid Sodium Fires, SAND2010-5299C, Tara J. Olivier, John C. Hewson, Thomas K. Blanchat, Steven P. Nowlen, Sandia National Laboratories, Albuquerque, NM.

TEV-1832, 2013, “Overview of Anticipated Transient Test Experiments,” Revision 03, Idaho National Laboratory, March 1, 2013. 